\title{
Advances in Molecular Diagnostic Approaches for Biothreat Agents
}

\author{
Meghana Rastogi and Sunit K. Singh
}

\subsection{Introduction}

Bioterrorism is the purposeful and intentional delivery of bioweapons by non-state actors to harm humans, livestock and agriculture. The Biological Weapon Convention (BWC) was established in 1972, banning the development, production and stockpiling of microorganisms and toxins that can lead to mass destruction. The Center of Disease Control and Prevention classified bioterrorism agents into three major categories: Category A, B and C. The categorization depends upon the following criteria: (1) the easy dissemination (person-to-person) of biologically active infectious agents, (2) a major public health concern and causing a high case fatality rate both in humans and/or livestock, and (3) the creation of panic and terror among people [1].

Prior to the development of high-end diagnostic tools, basic microscopy techniques used to be a primary tool in the diagnosis of disease. Microscopy played a pivotal role in diagnosis of bacterial pathogens and helped to enumerate pathogens in different samples (e.g., blood, urine, sputum, stool). Different stains (e.g., gramstain, Rhodamine, Indian ink) on histopathological specimens differentiated and classified several bacterial strains. The non-cultivable viruses, like rotaviruses, hepatitis A virus, and Norwalk virus, were also identified through microscopic techniques. Diagnosis was based on the morphological features of bacteria and virus particles, which required large amounts of samples, In the case of viruses, a high viral titer $\left(10^{5}\right.$ to $10^{6}$ virus particles $\left./ \mathrm{ml}\right)$ was needed. In addition, sample losses were high during sample preparation (electron microscopy, EM), either due to sample dehydration or charging of biomolecules (bacteria and viruses), which used to result in reduced contrast and performance. Further, microscopic techniques

M. Rastogi $\cdot$ S. K. Singh $(\bowtie)$

Molecular Biology Unit, Institute of Medical Sciences, Banaras Hindu University (BHU), Varanasi, India 
required expertise and trained manpower. Advancement in the technology led to the development of transmission electron cryomicroscopy, for which specimens are preserved at $-150{ }^{\circ} \mathrm{C}$ for maintaining the amorphous texture and for avoiding any ice-crystal damage. Nonetheless, the technique requires a high amount of sample $(\sim 1 \mathrm{mg} / \mathrm{ml}$ of virus particles). In addition, bacteria are far too thick for transmission electron cryomicroscopy to allow resolution of structural details [2-4]. The amalgamation of EM with cell culture practices greatly contributed in the diagnosis of bacterial and viral pathogens.

Immunochromatographic assays, polymerase chain reaction (PCR) and enzymelinked immunosorbent assays (ELISAs) have been developed for the detection of biothreat agents. With different types of immuno-based and chip-based biosensors, biothreat agents are quickly and sensitively detected. Scientists are encouraged to use nucleic acid amplification tests (NAATs), for real-time detection of DNA and RNA using fluorescent dyes through multiplex polymerase chain reaction (PCR) assays, in which multiple pathogens can be diagnosed in a single run. PCR amplification cannot produce a large amount of high-throughput data, but next-generation sequencing (NGS) platforms provide an unbiased-in depth analysis of near-complete genomes. Molecular diagnostic techniques (Microarrays, PCR and NGS) are time saving and precise in the detection and discovery of micro-organisms in a given sample. Development of quantitative, multiplex platforms is imperative for the specific diagnosis of such pathogens, and these platforms can be easily used as point-of-care (POC) molecular diagnostic tools. With automation and miniaturization, microfluidics-based chips can be easily used as a POC platform. In addition, microfluidics integrated with various other techniques such as PCR, ELISA, and isothermal amplification enhance the sensitivity and specificity of the POC platform within financial and time constrains. These molecular diagnostic tools can be used in surveillance programs intended for biodefense preparedness.

\subsection{Latest Diagnostic Techniques}

\subsubsection{Immunological Methods}

\subsubsection{Lateral-Flow Immunochromatographic Assays}

Detection of biothreat agents by (monoclonal or polyclonal) antibodies is a standard approach in clinical diagnosis. The basic principle is the formation of an antigenantibody complex on a solid surface followed by the visual readout. These tests are qualitative and semi-quantitative (intensity of color readout), quick (less than $20 \mathrm{~min}$ ), cost-effective, user-friendly, and require minimal settings. Therefore, these assays are an attractive tool for POC diagnosis/prognosis in a surveillance program.

Immunochromatographic lateral flow assay are used for the detection of pathogens. Gold nanoparticles or carbon/silver/magnetic beads, upconverting phosphors and latex colored bead capture detector antibodies (a detector antibody detects the presence/absence of an analyte in a given sample) on a dry solid surface. 
Once the diluted specimen is added, the detector antibodies form a complex with the cognate antigen, and the color readout indicates the test result [5-7]. A multiplexed suspension-based immuno-array can detect five biothreat agents (i.e., Yersinia pestis, severe acute respiratory syndrome coronavirus [SARS-CoV], staphylococcal enterotoxin B (SEB), ricin) in powder samples with a limit of detection (LOD) of 111 colony forming units $(\mathrm{CFU}) / \mathrm{ml}, 20 \mathrm{CFU} / \mathrm{ml}, 110 \mathrm{pg}, 5.4 \mathrm{ng}$, and $2 \mathrm{ng}$ respectively [8].

Many rapid diagnostic kits (RDKs) are available for the detection of biothreat agents. The ENVI Assay System Gold (Environics) is a lab-in-a-box device that detects various biothreat agents within 20 min [9]. New Horizon Diagnostic Inc. offers detection kits available for various biothreat agents in patient, environment, food, and water samples [10]. Response Biomedical Inc., developed RAMP ${ }^{\circledR}$ (Rapid Analyte measurement platform) for the detection of influenza A (FluA) and B (FluB) viruses, Bacillus anthracis, variola virus, and ricin and botulinum toxins. This platform consists of a fluorescent reader and a disposable single-use cartridge that provides specific on-field detection of pathogens [11]. Similarly, GenPrime developed a bio-detection system for the detection of US Centers for Disease Control and Prevention-listed bioterrorism agents along with others agents [12] (Table 13.1).

\subsubsection{Enzyme-Linked-Immunosorbent-Assay}

ELISA is the most widely used method detecting enzyme-linked antigen-antibody complexes on a solid phase. The technique is user-friendly, sensitive, specific, and cost-effective [14]. The method quantifies the antigen/antibody complexes in a given sample and is used as an in-vitro diagnostic tool in clinical laboratories.

Different types of ELISAs are in use for the pathogen detection such as: sandwich, direct, indirect, and competitive ELISAs. These different formats detect biothreat agents such as F. tularensis, B. anthracis, Y. pestis, Brucella abortus, Burkholderia pseudomallei, Ebola virus (EBOV), or Marburg virus [15-21].

The integrative multiplex assay and sampling system has been reported to identify eight biothreat agents (B. anthracis, F. tularensis, Y. pestis, Brucella spp., B. mallei, ricin toxin, botulinum toxin $\mathrm{A} / \mathrm{B}$, and $\mathrm{SEB}$ ) within $15 \mathrm{~min}$. The assay is a coded strip containing immobilized antibodies to identify these agents from surface, powder or liquid samples (http://www.bbidetection.com/products/biothreat-detec tion-imass-device/).

\subsubsection{Time-Resolved Fluorescence Immunoassay and Immunomagnetic Separation Electrochemiluminescence Assay}

Time-resolved fluorescence immunoassay (TRF) is a version of immunoassay with extended fluorescence decay time. The long fluorescence signal helps to measure the signal after the background noise has subsided. TRF assays can detect botulinum toxin in patient samples at low concentrations $(0.01 \mathrm{pM})$ [22]. The commercialized platform, dissociation-enhanced lanthanide fluorescence immunoassay, was developed by Perkin-Elmer for the detection of various pathogens. The test is similar to ELISA: a 96-well plate is coated with streptavidin and Europium- $\left(\mathrm{Eu}^{3+}\right.$, lanthanide 
Table 13.1 Different platforms for detection of pathogens and toxins

\begin{tabular}{|c|c|c|c|c|}
\hline & Product & Company & Pathogens/Toxins detected & $\begin{array}{l}\text { Total } \\
\text { run time }\end{array}$ \\
\hline 1. & $\begin{array}{l}\text { NIDS }^{\circledR} \text { handheld } \\
\text { biothreat assay and } \\
\text { handheld reader }\end{array}$ & $\begin{array}{l}\text { ANP } \\
\text { technologies }\end{array}$ & $\begin{array}{l}\text { Bacillus anthracis, vaccinia virus, } \\
\text { Brucellae, Venezuelan equine } \\
\text { encephalitis virus, Listeria, SEB, } \\
\text { Francisella tularensis, botulinum } \\
\text { toxin A, Vibrio cholerae, } \\
\text { Escherichia coli } 0157 \text {, ricin, } \\
\text { Coxiella burnetii, Yersinia pestis, } \\
\text { Salmonella } \text { sp. }\end{array}$ & $15 \mathrm{~min}$ \\
\hline 2. & $\begin{array}{l}\text { PRO STRIPS } \\
5 \text { Agent biowarfare } \\
\text { threat detection kit }\end{array}$ & $\begin{array}{l}\text { ADVNT } \\
\text { Biotechnology }\end{array}$ & $\begin{array}{l}\text { B. anthracis, ricin, botulinum toxin } \\
\mathrm{A} \text { and } \mathrm{B}, Y \text {. pestis and SEB }\end{array}$ & $\begin{array}{l}\text { Not } \\
\text { specified }\end{array}$ \\
\hline 3. & Zephyr & $\begin{array}{l}\text { PathSensors, } \\
\text { Inc. }\end{array}$ & $\begin{array}{l}\text { B. anthracis, } Y \text {. pestis, ricin, } \\
\text { F. tularensis, orthopoxviruses, } \\
\text { Salmonella } \text { sp. }\end{array}$ & $15 \mathrm{~min}$ \\
\hline 4. & PrimeAlert & $\begin{array}{l}\text { GenPrime, } \\
\text { Inc. }\end{array}$ & $\begin{array}{l}\text { Ricin, botulinum toxin, SEB, } \\
\text { F. tularensis, Y. pestis }\end{array}$ & $15 \mathrm{~min}$ \\
\hline 5. & $\begin{array}{l}\text { ENVI Assay } \\
\text { System Gold }\end{array}$ & Environics Oy & $\begin{array}{l}\text { Ricin, botulinum toxin, SEB, } \\
\text { orthopoxviruses, B. anthracis, } \\
Y \text {. pestis and } F . \text { tularensis }\end{array}$ & $<20$ min \\
\hline 6. & Aegis 1000 & $\begin{array}{l}\text { BioDetection } \\
\text { Instruments } \\
\text { (BDI) }\end{array}$ & $\begin{array}{l}\text { Foodborne pathogens, toxins, } \\
\text { infectious agents, protein } \\
\text { biomarkers, waterborne pathogens }\end{array}$ & $<30$ min \\
\hline 7. & $\begin{array}{l}\text { RAMP } \\
\text { 200 Biowarfare } \\
\text { Detection System }\end{array}$ & $\begin{array}{l}\text { Response } \\
\text { Biomedical } \\
\text { Corporation }\end{array}$ & $\begin{array}{l}\text { B. anthracis, ricin, botulinum toxin, } \\
\text { variola virus }\end{array}$ & $>30 \mathrm{~min}$ \\
\hline
\end{tabular}

Adapted from http://www.cbrnetechindex.com/Biological-Detection/Technology-BD/Immunologi cal-BD-T/Lateral-Flow-Hand-Held-Immunoassay-BD-I [13]

series) tagged detector antibody. The immobilized Eu-tagged antibody produces a fluorescent signal when it interacts with the antigen and releases Europium. The limit of detection of the system is $4-20 \mathrm{pg} / \mathrm{ml}$ [23].

In the IMS-ECL assay, the immunomagnetic separations are coupled with electrochemiluminescence assay (ECL) for the rapid detection of biothreat agents, B. anthracis, SEB toxins, and Clostridium botulinum in clinical specimens within $1 \mathrm{~h}$ with the LOD ranging from $1 \mathrm{pg} / \mathrm{ml}$ to $100 \mathrm{pg} / \mathrm{ml}$ [24].

\subsubsection{Biosensors}

A biosensor is an analytical device integrated with biologically active components, bioreceptors, and transducers for detection of analytes in a given sample. Bioreceptors may be enzymes, antibodies, single-stranded DNAs (ssDNA), aptamer proteins, or cells. Methods for detection of pathogen/toxins using biosensors are rapid, sensitive, and cost-effective. Immunoassays-based biosensors detect specific antigens in patient sample(s) or identify biomarkers for studying the host-immune 
response during infection [25]. Scientists using biosensor(s) may opt for either labelfree assays or labeled assays for detection of an analyte. A label-free assay detects the presence of an analyte directly through a transducer that can be an optical, electrical or mechanical [26]. In contrast, labeled assays use a second detector coupled with an enzyme, fluorophore or radioisotope to detect an analyte [14, 2729].

The integrated multiplexed microarray biosensor CombiMatrix ElectraSense microarray detects $Y$. pestis, B. anthracis, and SEB. The LOD for SEB and $Y$. pestis is $5 \mathrm{pg} / \mathrm{ml}$ and $10^{6} \mathrm{CFU} / \mathrm{ml}$, respectively [30]. The electrochemical multiplexed immunosensor with the indirect labeled assay can diagnose F. tularensis infection with a LOD of $1000 \mathrm{CFU} / \mathrm{ml}$ within $25 \mathrm{~min}$ [31]. Furthermore, a piezoelectric immunosensor identifies $F$. tularensis with an LOD of $10^{5} \mathrm{CFU} / \mathrm{ml}$ within 5 min [32].

Biosensor-based detection of EBOV glycoprotein $\left(\mathrm{GP}_{1,2}\right)$ is based on surface plasmon resonance and a quartz crystal microbalance sensor [33]. The on-paper gene circuit and visualization platform detects small molecules and RNA and strainspecific EBOV molecular patterns. This platform is cost-effective, quick and sensitive and can be used in industry, research, and biodefense programs [34].

A cell-based biosensor named CANARY (Cellular Analysis and Notification of Antigen Risks and Yields) developed at Massachusetts Institute of Technology detects emerging disease pathogens or biothreat agents relevant in sectors such as biodefense, agriculture, and food safety. Within the CANARY biosensor, engineered B lymphocyte cells express a calcium-dependent bioluminescent protein, aequorin, coupled with an antigen-specific membrane-bound antibody. The antigenantibody binding activates an intracellular calcium ion channel, and aequorin will emit light $[35,36]$. The, CANARY technology was commercialized by PathSensors Company for developing the BioFlash-E Biological Identifier and by Zephyr for screening liquid and powder samples for biological threat agents and toxins. The biosensor is a stand-alone, state-of-the-art device that can be used for both indoor and outdoor applications with an LOD of less than $100 \mathrm{CFU} / \mathrm{ml}$ within $5 \mathrm{~min}$ and 2-15 min, respectively [35]. The various types of advanced biosensors and their applications in the detection of biowarfare agents and infectious pathogens were extensively reviewed elsewhere [37]. The various types of biosensors used for the detection of biothreat agents are listed in Table 13.2.

\subsubsection{Nucleic Acid-Amplification-Based Techniques}

The development of PCR by Kary B. Mullis in 1987 revolutionized molecular diagnostics in clinical laboratories. PCR rapidly detects both biothreat agents and other pathogens in small patient samples in minimal time without compromising sensitivity or specificity. The basic principle of PCR is the isolation of nucleic acid (DNA, RNA) from a given sample and amplification by using a set of primers and thermostable polymerases. Later, the amplified products can be analyzed on gel electrophoresis or by using fluorescence-based detection systems. 


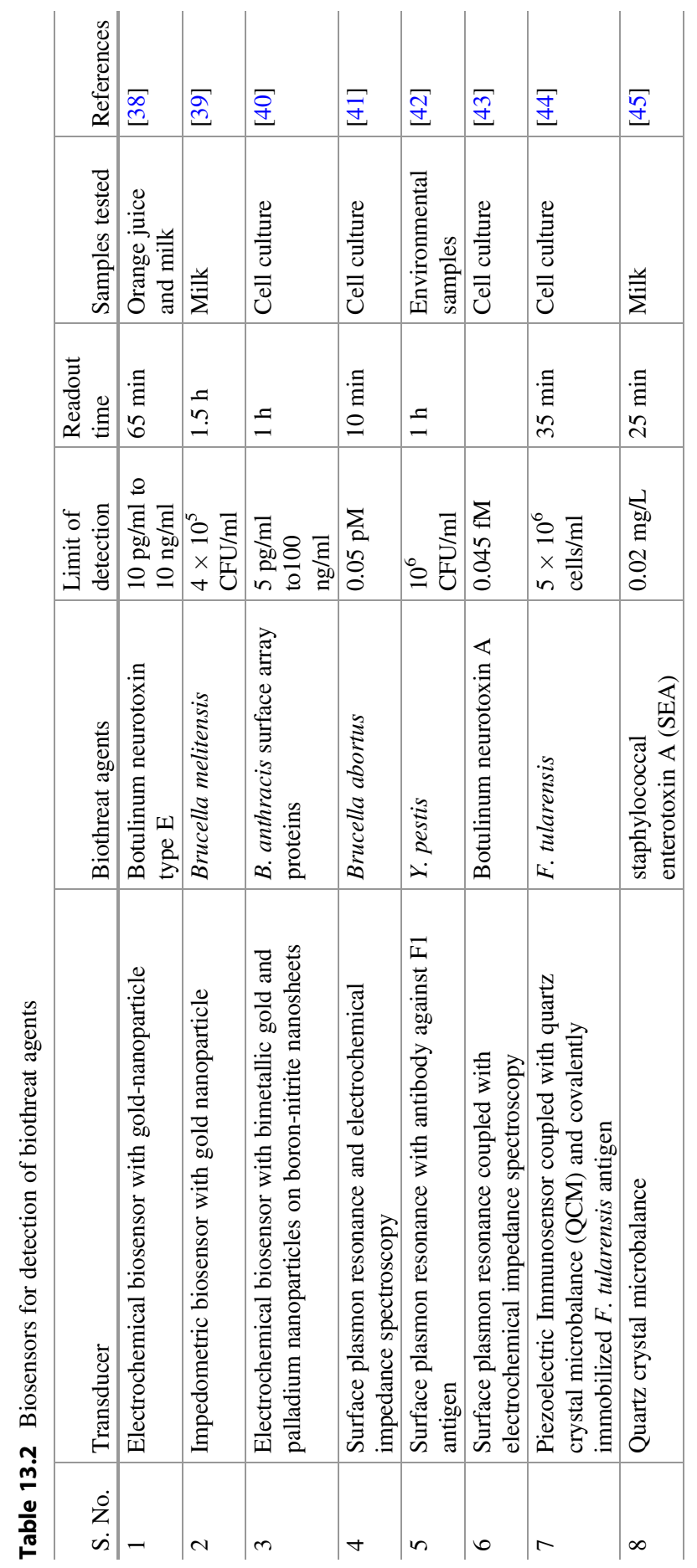


Originally developed PCR was used for virus detection in early 1990s [46]. However, post-amplification contamination and false positives were major drawbacks. New and improved versions of PCR have been introduced, called Nucleic Acid Amplification Tests (NAAT). Following the detection of SARS-CoV in 2003 and swine influenza A (H1N1) virus in 2009, NAAT has become an integrative part for clinical diagnostics and detection of bio threat agents [47, 48]. Real-time PCR, quantitative-PCR (q-PCR), and reverse transcription-PCR (RT-PCR) are widely used for the detection and quantification of pathogens [49]. The q-PCR platform quantifies the amount of amplified product in "real-time" by using fluorescent dyes such as SYBR green and light emission upon extension primers, or using probebased detection systems such as TaqMan ${ }^{\mathrm{TM}}$, scorpion probes, and molecular beacons. In RT-PCR, the complementary-DNA (cDNA) copy is synthesized by using reverse transcriptase, which can be amplified later by using gene-specific primers and polymerase enzyme. The human and avian influenza A viruses can be detected in patient samples by using RT-PCR [50, 51].

TaqMan probes have been developed by combining gene specific primers with fluorescently labeled probes. TaqMan chemistry employs the $5^{\prime}-3^{\prime}$ exonuclease activity of Taq polymerase, which cleaves the probe-containing reporter and quencher [52]. TaqMan-based qPCR panels detect and quantify filoviruses, arenaviruses, and hantaviruses with an LOD of 0.001-10 PFU/PCR [53, 54].

Although probe-based or non-probe-based methods are commercialized for pathogen detection the detection of RNA viruses is still a challenging task. The errorprone replication of RNA viruses results in changes in target gene sequences, making standard primer/probes ineffective over time. Consensus PCR assays based on primers and probes with wobble codes (degenerate primers) can detect various biothreat agents such as paramyxoviruses in bats and rodents [55, 56].

In nested PCRs, two sets of primers (hemi-nested and fully-nested) are used for amplification. This method detected influenza A virus in 2001 [57, 58]. Several laboratories do not use nested-PCR due to increased work load with double amplification process and higher chances of contamination [57, 59].

Multiplex RT-PCR has been increasingly used by diagnostic laboratories for the detection of multiple pathogens in a single run. The technique is efficient and less time-consuming than singleplex PCR, even in detecting co-infections in patient samples. This technique minimizes false positives, is highly sensitive, and aids in better diagnosis and prognosis than singleplex PCR. The multiplex RT-PCR platform detects and differentiates between the influenza A, B and C viruses [60].

During the Operation Iraqi Freedom 2003, US Marines troops were infected with multiple Shigella sp. and Norwalk virus, resulting in an outbreak of gastroenteritis. Multiplex-RT-PCR, enzyme immunoassay and sequencing technologies confirmed the presence of these pathogens [61]. The novel set of primers and probes are used with an LOD of $>95 \%$ in in-vitro transcribed RNA technique [62]. The multiplex qRT-PCR platform detects EBOV and Marburg virus by using conserved regions of the genomes of these viruses with the sensitivity of 28.6 copies $/ \mu 1$ and 30.5 copies $/ \mu 1$, respectively [63]. The outbreak of swine influenza in 2009 led to the development of multiplexed PCR-microfluidics and a silicon nanowire module for sequencing. 
These POC devices have a sensitivity of $20-30 \mu \mathrm{g} / \mu \mathrm{l}$ to detect H1N1 influenza A virus in samples [25]. In addition, the World Health Organization (WHO) licensed RT-PCR for detection of Middle East respiratory syndrome coronavirus in 2012 [64]. Nguyen et al. [65] developed a multiplex PCR assay for the detection of E. coli, Salmonella and Listeria monocytogenes in patient samples and food samples with the sensitivity of $10 \mathrm{CFU} / \mathrm{ml}[65]$.

Many multiplex PCR kits have been developed for the quick detection of various biothreat agents. Altogether, the sensitivity and specificity of multiplex PCR assays are very good, and the assays can be used in routine diagnosis [66]. The Food and Drug Administration (FDA) licensed the use of the $\mathrm{xTAG}^{\circledR}$ respiratory virus panel (developed by Luminex Corporation, USA), which is a multiplex molecular method for the detection of respiratory viral infections. Pillet et al. 2013 reviewed elsewhere the six commercially available kits for the diagnosis of acute respiratory infections [67]. Human respiratory syncytial virus (type A and B) and FluA and FluB nucleic acids can be detected in one-step multiplex RT-PCR assay named, ProFlu-1 (developed by Prodesse, Waukesha, WI) [68].

The GeneXpert technology was developed by Cepheid, USA, and is based on the use of microfluidics and multiplexed RT-PCR for the detection and diagnosis of various pathogens. In 2010, WHO endorsed the GeneXpert Mycobacterium tuberculosis and rifampicin resistance assay for the diagnosis of multi-drug resistant and extensively-drug resistant tuberculosis . This platform is rapid, user-friendly, and has a clinical sensitivity of $98-100 \%$ and a specificity of $99 \%$ [69-73]. The GeneXpert platform detects and analyzes $B$. anthracis in clinical isolates within 90 min and has an LOD of $10 \mathrm{CFU} / \mathrm{ml}$ and 100\% specificity [69]. Methicillin-resistant Staphylococcus aureus infections are also rapidly diagnosed by using the GeneXpert platform from clinical specimens [74].

After the Ebola virus disease outbreak in 2013, the GeneXpert platform was endorsed by both WHO and FDA under emergency use authorization. The assay used for the diagnosis of EBOV performed better in the field compared to other RT-PCR assays and culture methods [54, 75-77]. Real-time PCR or immunofluorescence assays are used to diagnose acute $\mathrm{Q}$ fever using clinical specimens (blood or formalin-fixed tissues) $[78,79]$. The Primerdesign Company commercialized the Genesig Easy kit for the detection of Coxiella burnetii with a specificity of $66.6 \%$ and a sensitivity of $100 \%$ [80]. LightCycler real time PCR coupled with RET probes (Roche Applied Science) can be used to diagnose orthopoxvirus infection with an LOD of 5-10 copies of virus DNA in 45 min [81].

A broad-spectrum PCR coupled with electrospray ionization mass spectroscopy run on an automated platform developed by Abbott-PLEX-ID [82] is able to detect 10 bacterial and 4 viral biothreat agents listed by the National Institute of Allergy and Infectious Diseases and the U.S. Department of Agriculture, and U.S. Department of Health and Human Services [83]. The IRIDICA is a combination of PCR and electrospray ionization mass spectroscopy techniques for quick and specific detection of pathogens in patient samples. Bloodstream infections, including both bacterial and yeast, may be analyzed by the IRIDICA BAC BSI assay [66]. 


\subsubsection{Next Generation Sequencing}

Sanger and Gilbert introduced DNA sequencing in 1977. Using their method, a DNA sequence can be deciphered by adding a terminal di-deoxy nucleotide phosphates (ddNTPs) labeled with fluorescent-dye by DNA polymerase in a reaction mixture which terminates the reaction. Later, the terminated nucleic acid stretches can be detected by capillary electrophoresis, and the laser excitation values are captured on charge-coupled device (CCD) camera. The disadvantages of the system include inaccurate read out, formation of DNA secondary structures, and limitation to the short length of DNA sequences. Next-generation sequencing (NGS) opened new horizons for molecular diagnosis but still has limited use in clinical diagnosis due to the requirement of trained personnel, long duration, and sophisticated setup. This technique can be used for the detection of homopolymer or repeat sequences.

NGS is useful in the characterization of pathogen genomes, genetic mutations or drug resistance patterns, and novel pathogen discovery [84-90]. NGS application includes an unbiased in-depth analysis of complete genomes [91], whole transcriptome shotgun sequencing (WTSS) [92], whole exome sequencing and methylation sequencing, or candidate gene sequencing. Another major application of NGS includes metagenomic sequencing, which detects multiple microorganisms in homogenous or heterogeneous samples simultaneously even if microorganisms are present in low abundance. Further, NGS can be applied to non-cultivable microorganisms. The future of NGS promises great potential for the development of precision medicine. Second generation NGS includes the construction of cDNA libraries for amplification and sequencing genomes. The libraries are synthesized by fragmenting DNA strands and ligating them with adaptor molecules. Once the libraries are constructed, the adaptor-ligated sequences are amplified through emulsion PCR which uses immobilized adaptor-ligated sequences on microbeads or bridge PCR which uses solid-surface to form colonies. NGS is efficiently used for the detection of biothreat agents [93].

\subsubsection{454 Pyrosequencing}

The GS20 was the first second-generation sequencing method commercialized by 454 Life Sciences in 2005 (later acquired by Roche in 2007). This technology employs pyrosequencing chemistry in which three different enzymes, adenosine $5^{\prime}$ phosphosulfate (APS), luciferase, and apyrase are used. The pyrophosphates generated during the addition of nucleotides by DNA polymerases act as substrates for APS enzyme to produce adenosine triphosphate. Adenosine triphosphate is used for the conversion of luciferin to oxyluciferin by luciferase, and this conversion leads to the emission of light, which is captured by highly sensitive CCD cameras. Therefore, the amount of light produced is proportional to the number of nucleotides added to the growing chain. Apyrase degrades any unincorporated nucleotide.

The pyrosequencing system uses microscopic beads embedded with DNA sequences of 100-150 bp. The system amplifies the sequences by using emulsion PCR and provides 2,00,000 reads per run [94]. The upgraded versions of the GS20 genome sequencer, the 454 GS FLX Titanium platform, was introduced in 2007 and 
provides 4-6 million reads of $\geq 400$ bp-long sequences within $24 \mathrm{~h}$ [95]. The major drawbacks are the expensive reagents and inability of the system to distinguish between homopolymers (AAA or CCC), and hence the product was withdrawn from the market

\subsubsection{Illumina Sequencing}

Solexa introduced the HiSeq and MiSeq platforms for sequencing of shorter DNA templates in 2007. These techniques rely on the sequence-by-synthesis method using modified deoxyribonucleotide triphosphates labeled with fluorescent dyes for chain termination (similar to the Sanger method) and detection by a CCD camera. The 100-300 bp-long DNA ligated with adaptors is amplified on a solid surface through "flowcells" for bridge PCR amplification. The clonal amplification results in approximately more than 1 million copies of each 100-300 bp-long template. The laser excitation captures the emitted light and records the first base, the reaction is called "reversible terminator reaction". Thereafter, the cycle continues, and multiple sequence reads are recorded, aligned and compared to the reference template. Unlike 454 Pyrosequencing, which produces 1 million reads, the Hi-Seq platforms produces 120-1500 GB reads in 3-10 days, whereas the MiSeq platforms can produce up to $0.3-15$ GB reads within 1-2 days for clinical testing or laboratory purposes [96]. The Illumina can detect $B$. anthracis both from the soil and aerosol samples, with a LOD of 10 genomic copies of DNA [97].

\subsubsection{Sequencing by Oligonucleotide Ligation and Detection}

Sequencing by oligonucleotide ligation and detection (SOLiD) was commercialized by Life technologies and released by Applied Biosystems in 2008. The technique is mostly similar to Roche or Illumina sequencing but differs by using DNA ligases during sequencing. After the library preparation and colony formation, sequences are detected by a modified probe named "interrogation probe." The probe is an octamer consisting of degenerate sequences covalently attached to a fluorescent dye. The first two bases are specific to the DNA template and provide 16 different combinations for annealing (e.g., AT, AG, AA, AC). The interrogation probe provides a free $5^{\prime}$ phosphate group instead of providing a free $3^{\prime}$ hydroxyl group for ligation during each step of reaction by thermostable DNA ligases. The fluorescent signals are recorded by four different channels before the last $3 \mathrm{bp}$ are cleaved for the next cycle. The newly synthesized sequence is removed, and a new complementary primer binds to the $\mathrm{n}-1$ region of DNA sequence and continues the annealing and ligation cycles. Following this approach, every DNA sequence is sequenced twice, thereby providing accuracy of $99.94 \%$ to the system. The read length of this technique ranges from 25 to 35 bp-long sequences [98]. The longer duration time (7-14 days) and requirement of skilled personnel are drawbacks of this system $[99,100]$. Strain-specific polymorphisms of B. anthracis and $Y$. pestis were studied by using SOLiD high-throughput-sequencing [101] with high genome coverage and low error rates ( $>99.99$ accuracy). 


\subsubsection{Ion Torrent}

The ion torrent platform was released in 2010 by DNA Technologies. The method uses semiconductor chips incorporated with an ion-sensitive field-effect transistor (ISFET) sensor. The ISFET is an electrical biosensor that records the changes in concentrations of $\mathrm{H}^{+}$or $\mathrm{OH}^{-}$ions. ISFET sensors are used to measure the changes in the $\mathrm{H}^{+}$concentration after every addition of a nucleotide by DNA polymerases during a sequencing step. The biosensors convert the chemical energy to electronic signals. These ion sensors are situated right beneath microwells containing microbeads covered with amplified target molecules. The microwell chip is successively flooded with only one type of nucleotide at a time. When the nucleotide is complementary to the target template molecule at the leading position, the nucleotide will be incorporated into a growing nucleic acid. The earlier versions (2011) of ion torrents could read a 50 bp-long sequence with $99.99 \%$ accuracy and produced $100 \mathrm{MB}$ of data per run. The upgraded version, the ion personal genome machine (PGM ${ }^{\mathrm{TM}}$ ) reads up to $400 \mathrm{bp}$ with $>99.1 \%$ accuracy in $7.3 \mathrm{~h}$ [102]. The Ion proton system, the successor to the Ion PDM, can read up to $200 \mathrm{bp}$ within 2-4 h with $10 \mathrm{~GB}$ of data per read and can be used for genome sequencing, de-novo sequencing, chromatin immuno-precipitation (ChIP), transcriptome, exome, methylation patterns, gene expression by sequencing, and small RNAs [96].

NGS platforms have been integrated with several molecular diagnostic techniques which amplify even small amounts of nucleic acid randomly. This platform can detect both known and unknown pathogens in the clinical samples using the integrated digital transcriptome subtraction technique [103, 104]. The detection of a highly divergent rhabdovirus, Bas-Congo virus, through NGS highlights the potential of sequencing for the detection of novel viruses during major disease outbreaks [105]. The Ion Proton platform (BGISEQ-100) and Roche 454 v 4.9 were used for sequencing and phylogenetic and phylogeographic analysis of EBOV genomes during the major outbreak in 2013-2016 [106].

\subsubsection{Microarrays}

Microarray technology was established in 1995, when Ron Davis and Pat Brown used cDNA as a probe to quantitate the gene expression pattern in Arabidopsis [107]. Microarrays are miniature lab-on-chip devices made from glass or silicon, containing 25-70 mer-long complementary oligonucleotide probes spotted on the slide through mechanical deposition [107], inkjet printing [108] or through photolithography [109]. Every single spot on a microchip contains several folds (10 $\mathrm{nM}$ to $100 \mathrm{pM}$ DNA) of oligonucleotide copies. Depending upon the need, a microarray may have multiple signature probes for different microorganisms or a complete genome from a single microorganism. The commercialized microchips from Affymetrix and Illumina have been used for the detection of more than 20,000 to several million genes. Different types of microarrays are available (protein, peptide, carbohydrate, lipid,, tissue, reverse phase, or antibody microarrays). 
Steps in microarray protocols include sample preparation, labelling of probes with fluorescent dyes, hybridization of the sample on the chip, washing and image acquisition followed by data normalization, analysis and interpretation.

A highly broad-spectrum multiplexed-microarray, resequencing pathogen microarray of tropical emerging infections (TessArray ${ }^{\circledR}$ RPM-TEI 1.0, TessArae LLC, Potomac Falls, VA) detects and differentiates between 84 pathogens and 13 toxins, including Category A, B and C Pathogens with an LOD of $10^{4}$ per test. The tests are very sensitive and can further differentiate between EBOV, Machupo virus, and Lassa virus [110].

A pan-viral array named "ViroChip" was developed for the detection of viruses. The 70-mer oligonucleotide probes recognize the conserved regions (1600 probes) from 140 viral genomes, and can be used to detect viruses, such as human herpesvirus 8 , human respiratory syncytial virus, parainfluenza virus type 3 , adenoviruses, and multiple rhinovirus serotypes [111]. During the 2003 SARS outbreak, a DNA microchip was used for identification and sequencing the then-uncharacterized coronavirus isolated from SARS patients [112]. An improved and upgraded version of ViroChip detects viruses of 53 families and 214 genera using full-length viral genomes [113]. In addition, ViroChip was used for the diagnosis of acute respiratory tract infection in children. Similarly, the pan-microbial array named GreeneChipPm was developed for the quick and unbiased detection of bacteria in different samples. The platform includes densely spotted oligonucleotides $(29,495)$ from the GreeneChipVr v1.0 database. For bacterial and fungal/protozoan detection, 11,479 16s rRNAs and 18s rRNA sequences were used for pathogen surveillance and detection $[114,115]$.

A low-density oligonucleotide microarray can detect neurotropic viruses (meningitis and encephalitis) from cerebrospinal fluid and non-cerebrospinal fluid samples. Multiplex PCR-amplified virus sequences are hybridized to a panviral central nervous system array slide for the detection of echoviruses, human herpes virus (HHV)-2, -4, -5, -6BA,-6B, and -7, vesicular stomatitis Indiana virus, and polyomavirus JC1 [116]. These microarrays integrated with microfluidic scans detect influenza A virus [117], Y. enterocolitica [118], and Bacillus sp. in milk and various other samples. The success of microarray depends upon the sensitivity of the system to detect pathogens in a single sample even if the pathogens belong to same genus.

\subsubsection{Isothermal Amplification}

Isothermal amplification is a robust technique for exponential amplification of nucleic acids at a single temperature. This technique is a sequence-specific amplification without using a thermocycler, thereby cutting down the cost of instruments and making the technique easily available for POC platforms. The processing steps in isothermal amplification can be divided into three categories: (1) sequencespecific amplification, (2) enzymatic duplex melting and primer annealing, and (3) strand displacement using multiple PCR primers or strand displacement from a circular target and PCR extension with single-strand cutting. 


\subsubsection{Sequence-Specific Amplification}

Sequence-specific amplification is derived from a transcription-based amplification system, which includes transcription-mediated amplification (TMA) [119], nucleic acid sequence-based amplification (NASBA) [120], self-sustained sequence replication (3SR) [121], and signal-mediated amplification of RNA technology (SMART) [122]. Unlike PCR, the primer annealing and extension occurs at a constant temperature of $37{ }^{\circ} \mathrm{C}$, thereby reducing time and cost of equipment. This method can easily be automated and multiplexed.

These methods depend upon RNA polymerase activity for amplifying the nucleic acids (ssDNA or RNA) at an isothermal temperature, which may range from $30^{\circ} \mathrm{C}$ to $70{ }^{\circ} \mathrm{C}$ depending upon the reaction. The hot-start temperature of $95{ }^{\circ} \mathrm{C}$ breaks the double-stranded DNA into ssDNA; followed by the amplification at $41{ }^{\circ} \mathrm{C}$ (or for transcription-mediated amplification at $60^{\circ} \mathrm{C}$ ). Amplification occurs in two phases: during the linear phase, the promoter-primer containing $\mathrm{T} 7$ promoter region binds at the $5^{\prime}$ end of the target sequence and synthesizes cDNA with the help of avian myeloblastosis virus reverse transcriptase. Subsequently, the RNA-cDNA hybrid formed is degraded by RNase $\mathrm{H}$ with the release of cDNA. A second forward primer binds to the cDNA containing the T7 promoter region and extends via reverse transcriptase. The newly formed strand enters the amplification phase, in which T7 polymerase binds to the DNA and synthesizes complementary RNA, again followed by the linear phase. Thus, billion-fold copies of RNA or DNA are generated within 90 min (Fig. 13.1) [123].

\section{Signal Mediated Amplification of RNA Technology}

SMART is another type of isothermal amplification. It is based on the identification and amplification of the target sequence in the sample with the help of two single stranded oligonucleotide probes (extension probe and template probe). The template probe contains a T7 polymerase promoter sequence and a transcription template. These probes hybridize together with the target RNA or DNA and form a three-way junction or "T-like" structure. The Bst DNA polymerase, which lacks 5'-3' exonuclease activity is obtained from Bacillus stearothermophilus, which can amplify the nucleic acid at $70{ }^{\circ} \mathrm{C}$. Once amplified, the target RNA or DNA is used for synthesizing the complementary strand using the extension probe. Thereafter, $\mathrm{T} 7$ RNA polymerase synthesizes multiple copies of RNA from the formed DNA duplex (Fig. 13.2). An enzyme-linked oligosorbent assay quantifies the SMART-generated product. Amplicons are captured and detected by biotinylated probes and separated by microfluidics or through molecular beacons $[125,126]$. SMART detects genomic DNA (10 ng) and total RNA (0.1 ng) from E. coli in a few hours [127].

\subsubsection{Enzymatic Duplex Melting and Primer Annealing Method}

This method includes three techniques that circumvent the initial heating step for denaturing the DNA or RNA duplexes. Under in vivo conditions, DNA amplification is performed at an isothermal temperature, at which the DNA duplexes are opened by helicases and topoisomerases. The recombinase polymerase enzyme for amplification (RPA), helicase-dependent amplification (HDA) and rolling circle 


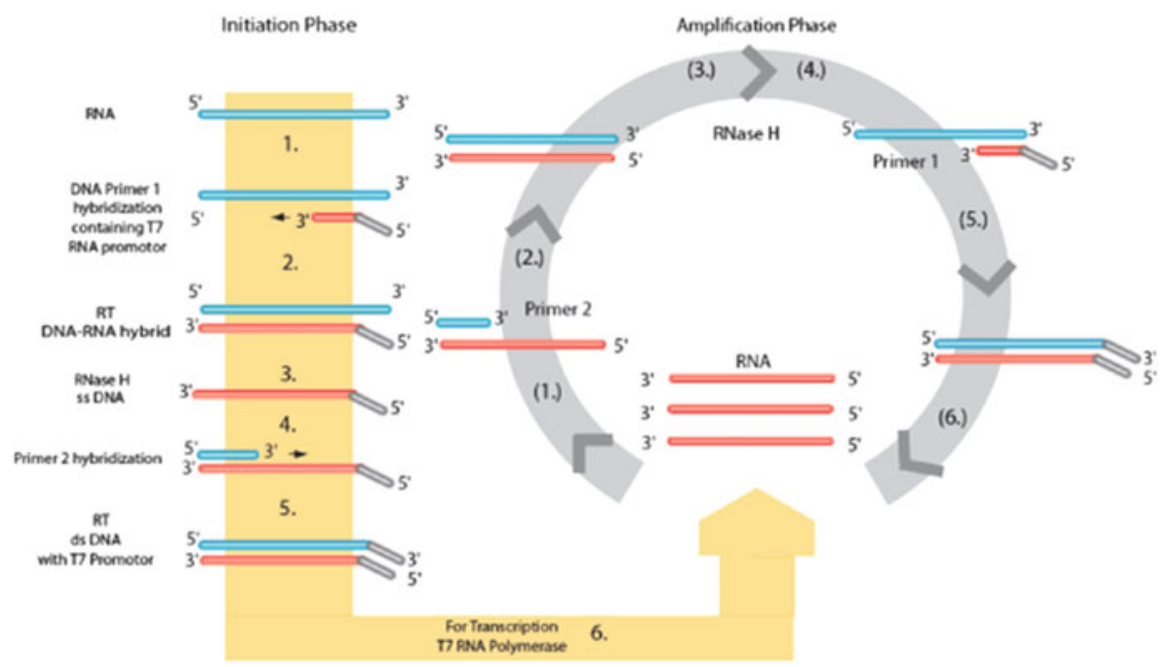

Fig. 13.1 Nucleic-acid-sequence-based Amplification (NASBA). Initial phase: 1. Annealing of DNA primer to RNA template; 2. RT for primer extension; 3. Removal of RNA by RNAse H; 4. Annealing of second set of primer to the newly synthesized DNA template; 5. Double strands of DNA are synthesized by RT; 6 . For transcription, T7 RNA polymerase produces several RNA copies. The amplification phase is similar to initial phase but more copies of RNA are produced steps 1-6. (Troger V and Niemann K 2015)

amplification (RCA) enzymes amplify the nucleic acids. This technique is less time consuming, than other Isothermal amplification based diagnostic techniques, and does not require any sophisticated instruments; therefore, this method can be adopted for POC diagnostic platforms.

\section{Recombinase Polymerase Amplification}

This technique utilizes three enzymes: recombinase, single strand binding proteins (SSBs), and strand displacement DNA polymerases. Initially, the recombinase enzyme pairs with the primer and binds to the target sequence, the SSBs then bind the displaced DNA strand and form a "D" loop like structure to stabilize the DNA. This displaced DNA provides a free 3 '-hydroxyl site for DNA polymerase to bind and amplify the target sequence. Therefore, both the strands are amplified exponentially within $20 \mathrm{~min}$. The amplified product can be visualized either by fluorescent probes or non-fluorescent probes. RPA can be easily multiplexed by using multiple primer set and can detect more than one disease simultaneously within min (Fig. 13.3). Crimean-Congo hemorrhagic fever virus (CCHFV-AY277672 Europe 1 strain) in patient samples was detected within 35 min using isothermal amplification [128]. A commercialized RPA kit (TwistAmp) was launched by TwistDx Inc.; Cambridge, UK, for the rapid detection of pathogens, like $Y$. pestis, within $1 \mathrm{~h}$ with a limit of detection for ssDNA and dsDNA up to $4.04 \times 10(-13)$ and $3.14 \times 10(-16)$ 


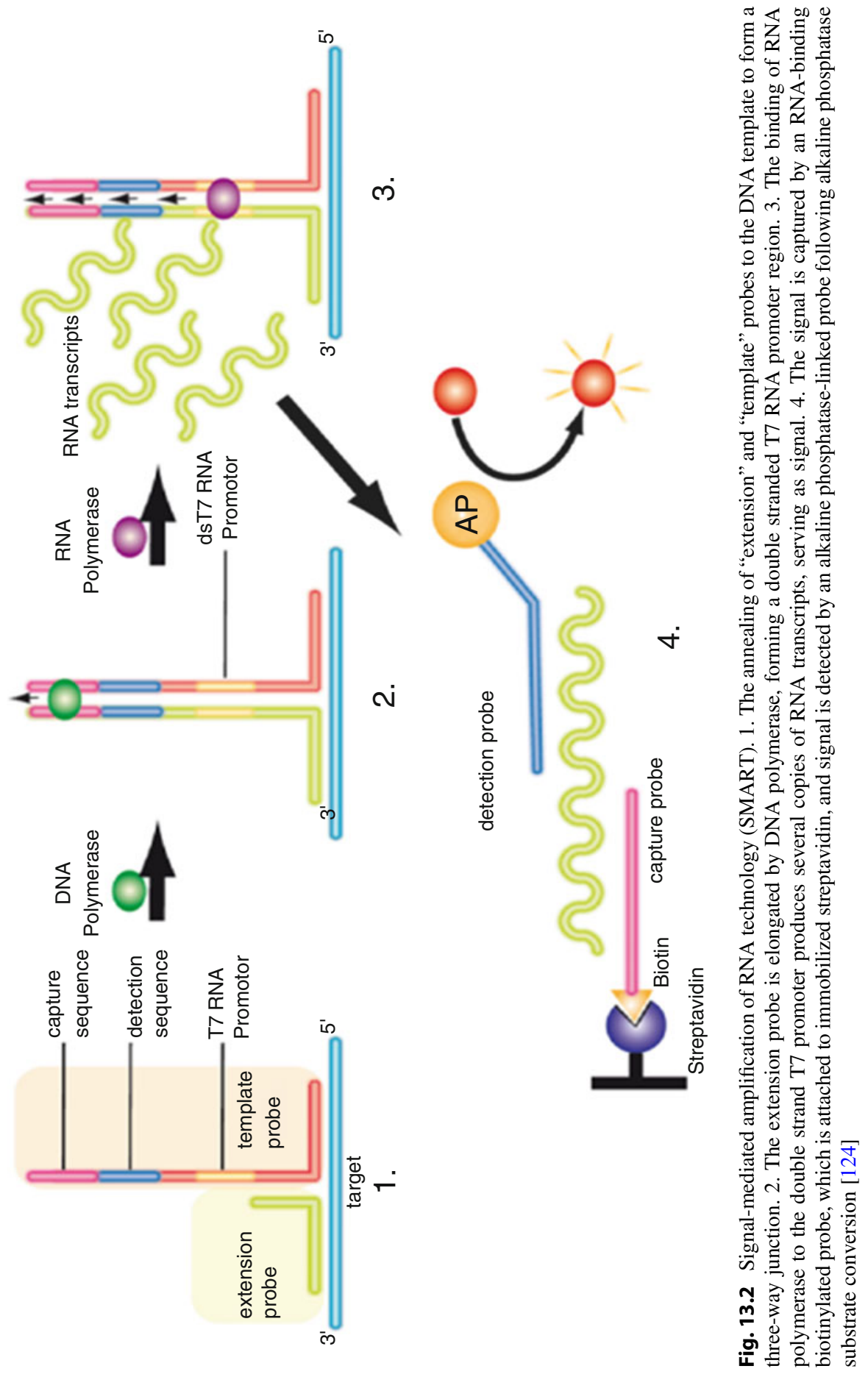




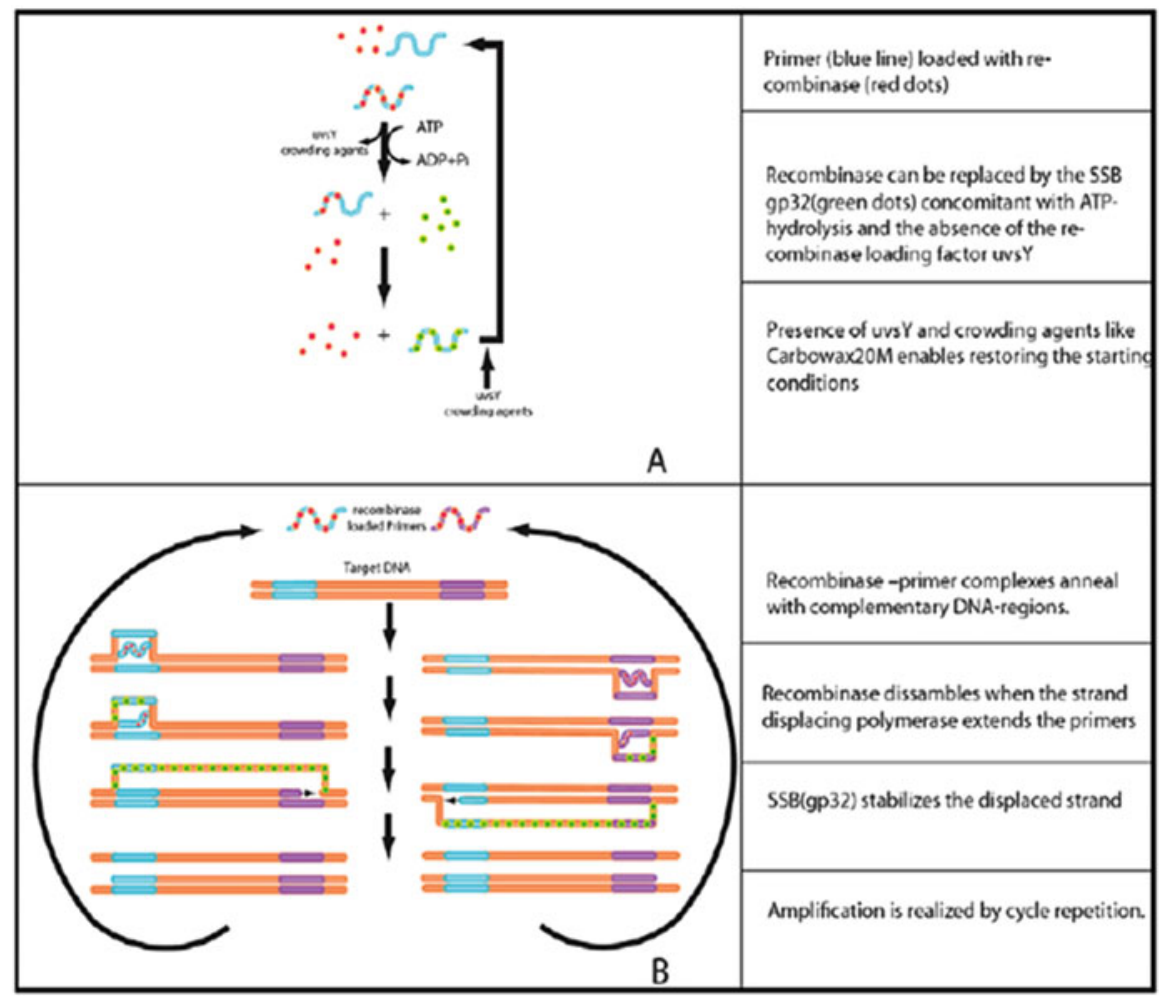

Fig. 13.3 Recombinase polymerase amplification (RPA). (a) The combination of the primerrecombinase complex and single-stranded- binding proteins (SSBs). (b) RPA cycle, in which the RPA complex anneals to the DNA template for initiation. Later, the strand displacement enzymes disassemble the recombinase and stabilize the strands by SSBs protein for further extension. Thereby, multiple copies are generated [124]

M [129]. C. burnetii was detected in formalin-fixed tissues and blood plasma of patients with 90\% clinical sensitivity using RPA-isothermal amplification [130].

A RPA and RT-RPA fluorescent based POC platform for the detection of potentially hazardous bioterrorism pathogens $(Y$. pestis, $F$. tularensis and B. anthracis), gram positive and negative bacteria (Salmonella enterica), DNA (vaccinia and variola viruses) and RNA (EBOV, Sudan virus, and Marburg virus) was developed, with a LODs ranging from 16-21 molecules within $10 \mathrm{~min}$ [131].

\section{Helicase Dependent Amplification (HDA)}

Vincent et al. used DNA helicases to unwind duplex DNA or RNA and hybridize primers onto the target sequence. The enzymes separate the strands at an isothermal temperature of $37{ }^{\circ} \mathrm{C}$, excluding the heating step [132]. The Mutl protein is a mismatch DNA repair protein found in E. coli that activates the DNA helicases and separates the strands. The SSBs proteins stabilize the unwinded duplex. The 


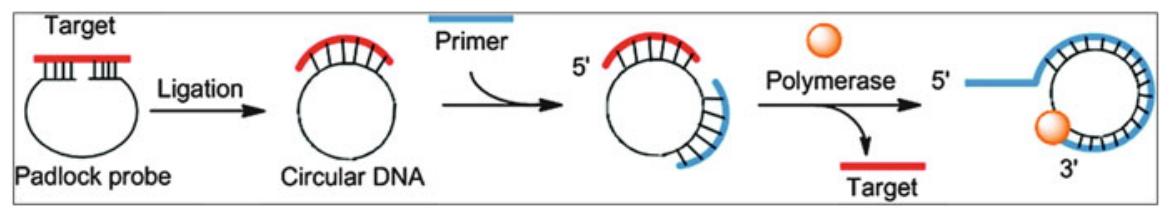

Fig. 13.4 Rolling circle amplification (RCA). The padlock probe anneals at a specific genomic location (ssDNA) forming a circular DNA and disassembles. The primers specific to the padlock probe and DNA polymerase anneal to the circular-DNA and amplify the template. These steps are performed at an isothermal temperature [124]

primers anneal to the target sequence, and DNA polymerases amplify the strands, thereby synthesizing million-fold copies of DNA within 120 min (Fig. 13.4). To further improve the sensitivity of the system, heat-stable DNA helicases derived from Thermoanaerobacter tengcongensis were used at $45^{\circ} \mathrm{C}[133,134]$. The endpoint results are quantified by using fluorescently-labeled probes, electrochemical detectors [135, 136], a droplet microfluidics system [137] or chip-based hybridization [138]. The HDA-TaqMan probe can detect $V$. cholerae and B. anthracis [139]. Motre et al. 2011 customized a HDA probe by reducing the detection time from 60 to $30 \mathrm{~min}$ [140].

\section{Rolling Circle Amplification}

RCA was first introduced in 1990s for amplifying the small circular DNA by using strand displacement DNA polymerases (e.g., phage phi-29 DNA polymerase of E. coli) [141]. RCA synthesizes ssDNA complementary to target DNA $\left(10^{5}\right.$ copies from 1 DNA copy) $[142,143]$ at an isothermal temperature $\left(30^{\circ} \mathrm{C}\right)$. The method is sensitive, simple and easy to perform; therefore, this amplification method is considered as an attractive tool for POC diagnosis in clinical settings. RCA detects bacterial and viral DNA/RNA [144-146]. The amplified product can be detected by fluorescent dyes, biosensors, gel electrophoresis, electric signals, luminescence or colorimetric assays.

Padlock probes have been introduced with RCA for linear DNA amplification. The probes have two target sequences of the linear DNA at the $3^{\prime}$ and $5^{\prime}$ ends. These probes hybridize, circularize, and ligate on the target DNA and serve as a template for strand displacement DNA polymerases, simultaneously elongating and displacing the amplified product. The technique can be coupled with the set of primers that hybridize with the amplified product and synthesize hyper-branched structures (Fig. 13.5).

A liquid and solid phase hyper-branched RCA for the rapid detection of SARSCoV RNA from clinical samples can detect a single-copy of SARS-CoV RNA in the patient sample and can be used in diagnostic setting for quick detection [147]. A colorimetric assay using hydroxy naphthol blue (HNB) coupled to hyper-branched RCA rapidly detected $\mathrm{H} 5 \mathrm{~N} 1$ influenza A virus with an LOD of $28 \mathrm{fM}$ in clinical isolates. An upgrade version detects H5N1 influenza A virus using a fluorometric real time platform. The LOD of the system was $9 \mathrm{fM}$ in clinical samples [148, 149]. 

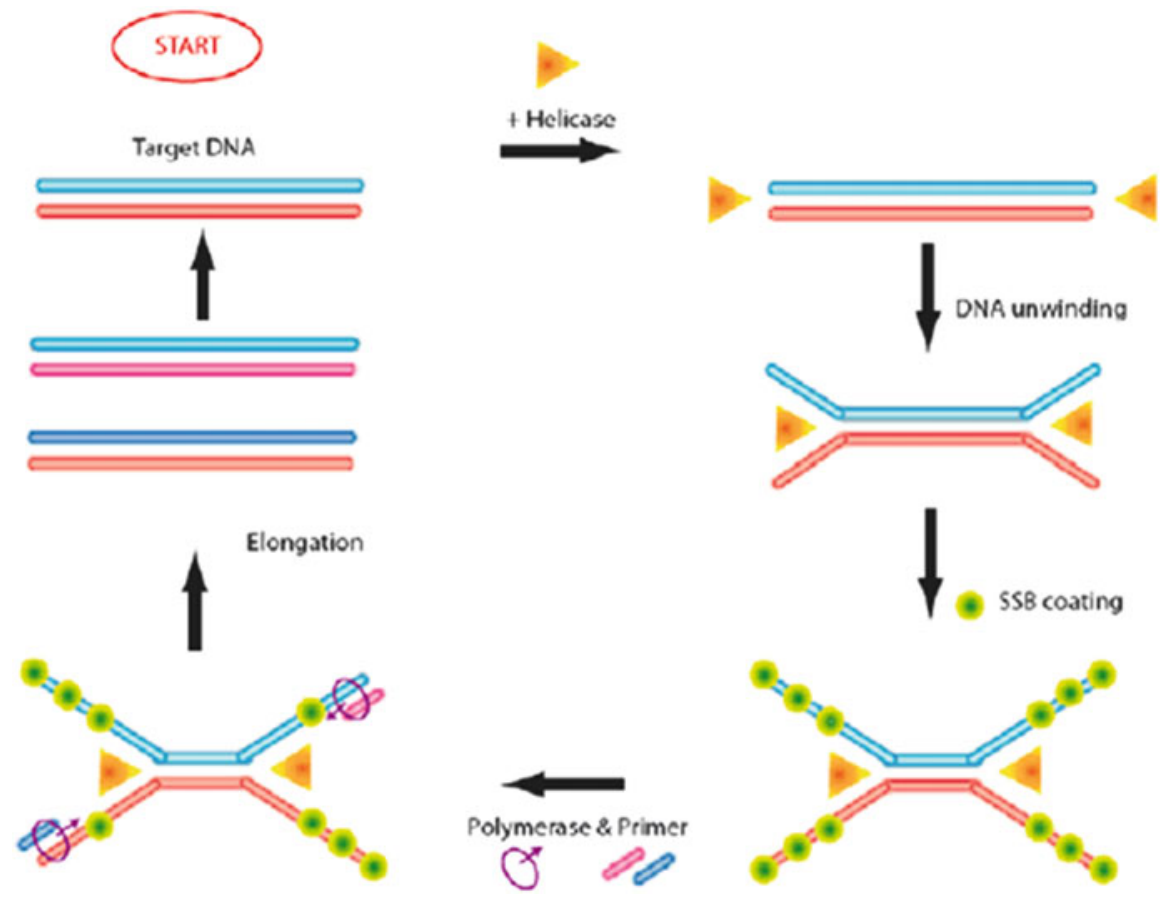

Fig. 13.5 Helicase-dependent amplification (HDA). The helicases bind to the DNA template and unwind the DNA template. The SBs stabilize the DNA strand. The primers and DNA polymerases bind to the DNA template and amplify the template [124]

Circle-to-circle amplification, another variant of RCA, detects circular DNA. Mahmoudian et al. 2008 integrated circle-to-circle amplification with a microchip electrophoresis system for the detection of $V$. cholerae with an LOD of $25 \mathrm{ng}$ of bacteria within 65 min $[150,151]$. An exponential linear RCA (with colorimetric detection for pathogenic bacteria, such as E. coli, Salmonella Typhimurium, and Clostridium difficile), was developed with LODs ranging from $10 \mathrm{fM}$ to $100 \mathrm{fM}$ of DNA. In this method, the amplified RCA products are cleaved by nicking endonucleases (Nb.BsrDI). The DNA fragments fold into G-quadruplex structures that form a complex with hemin and become DNAzymes. The DNAzymes undergo oxidation reactions that lead to a colorimetric detection [152].

\section{Loop-Mediated Isothermal Amplification}

Notomi et al., developed loop-mediated isothermal amplification (LAMP) in 2000 [153]. In this technique, the low copy number of DNA can be amplified up to $10^{9}$ copies of target DNA within $1 \mathrm{~h}$ at an isothermal temperature. The basic principle is based on highly processive strand displacement DNA polymerases (Bst DNA polymerases) with four primer pairs (recognizing six different regions of target DNA), which amplifies the DNA and ensures the selectivity of target identification. 
During the initial amplification, the four pairs of primers along with DNA polymerase amplify the DNA, forming a stem loop-like structure. The stem-loop structure becomes the template for cyclic amplification with two additional primer pairs and progresses to elongation and recycling. These additional primer pairs ensure the specificity of subsequent amplification, thereby providing a threefold amplification at every half cycle. The final amplified product consists of cocktail of stem-loop DNAs with different stem lengths and multiple loop structures (Fig. 13.6).

Apart from DNA, RNA can be amplified by LAMP using RT and Bst DNA polymerase [153]. Viruses, such as West Nile virus and SARS-CoV, can be detected by RT-LAMP assay $[154,155]$. The amplified product is visualized by using a turbidimeter $[155,156]$, gel electrophoresis, fluorescent detection reagents, or by observing the production of white insoluble precipitate of pyrophosphate ions with $\mathrm{Mg}^{2+}$ ions [157]. The fluorescent detection reagent, calcein, and the DNA binding dye, SYBR green, used in RT-LAMP assay detect the amplified product $[158,159]$. A low molecular weight cationic polymer, polyethylenimine, was used for genetic testing of West Nile virus by using Bst DNA polymerase at $63{ }^{\circ} \mathrm{C}$ [155].

LAMP is an excellent technique for POC applications. With advancement in microfluidic systems, LAMP has been successfully integrated for the specific and rapid detection of pathogens. A POC platform for the quick detection of pseudorabies virus used microLAMP ( $\mu$ LAMP), for on-site application with an LOD of $10 \mathrm{fg} / \mu \mathrm{l}$ in less than $1 \mathrm{~h}$ at $63{ }^{\circ} \mathrm{C}$ [160]. A similar microfluidic platform with the facility of multiplexing was developed for the detection of bacteria, with an LOD of 270 copies/ $\mu 1$ [160]. Wang et al. 2011 designed a device that combines isothermal amplification and magnetic-beads on microfluidics chip for the detection of methicillin-resistant $S$. aureus with an LOD of $10 \mathrm{fg} / \mu \mathrm{l}$ within $60 \mathrm{~min}$ [161]. E. coli and S. aureus were detected within $30 \mathrm{~min}$ with LODs of 20 and 30 copies/ $\mu$ l, respectively, by using an electrochemical sensor made from Ruthenium hexa-amine redox molecules to detect LAMP-amplified product [162].

\subsubsection{Strand Displacement Amplification}

The strand displacement amplification (SDA) method amplifies DNA by using a multifunctional probe that has a restriction endonuclease site at the $5^{\prime}$ end and a strand-displacement DNA polymerase at the $3^{\prime}$ end. This probe extends and displaces the nicked strand. Thereafter, the displaced strand acts as a template for the second probe, leading to exponential amplification. The amplified product can be detected by fluorescently-labeled probes, molecular beacons, or intercalating dyes. SDA has been integrated with various other detection methods like gold nanoparticle-based detection on lateral flow chip or a microelectric chip-array for the detection of several mutations [163, 164]. Westin et al. 2000 developed a multiplex SDA with multiple primers immobilized on a microarray chip [165], whereas Yang et al. 2002 developed a stacked micro-laboratory platform that uses electric field for immunoassays, DNA hybridization, and amplification by SDA. These systems efficiently analyze and handle different kinds of bacteria and toxins in the sample mixture [164]. 


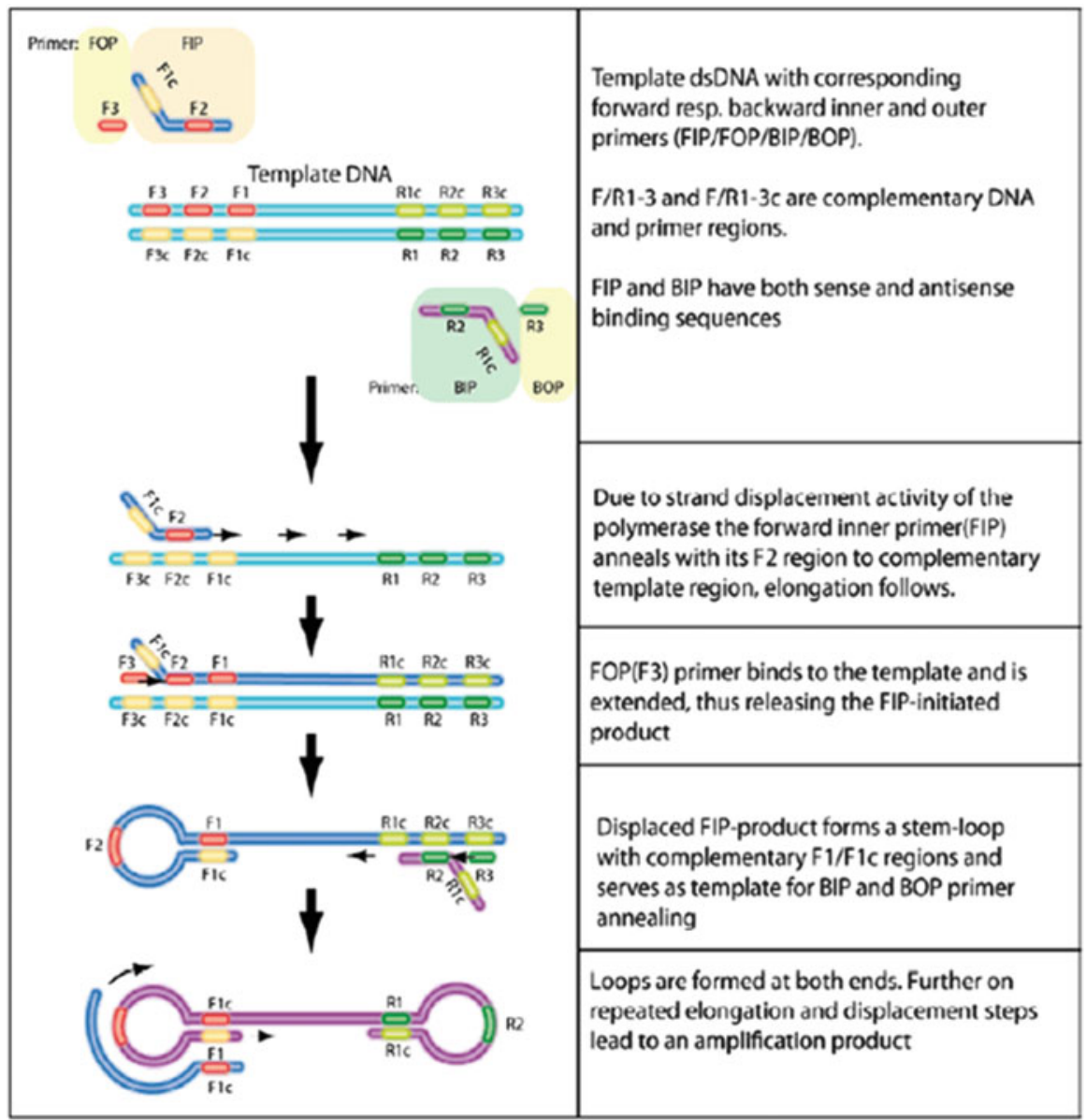

Fig. 13.6 Loop-Mediated Isothermal Amplification (LAMP). Four different primer pairs bind to different locations of the DNA template along with DNA polymerases. The Bst (highly processive strand displacement polymerase) polymerase then displaces and extends the DNA template along with the primer pair to form multiple copies of the DNA template [124]

\subsubsection{Microfluidics}

Microfluidics technology uses the close dimensions, preferably a channel that holds fluids with a capacity of $\mathrm{nl}$ to few hundred $\mu \mathrm{l}$, for both qualitative and quantitative analysis of a given sample. The basic principle behind microfluidics technology is to create a laminar flow between the channels. The flow of fluid can be regulated by pressure-driven pumps, such as syringe pumps or electrokinetic pumps. Electrokinetic pumps apply electro-osmosis through the walls to generate pressure and flow of fluid. Microfluidics offer multiple applications in the field of molecular biology, enzyme kinetics, capillary electrophoresis, immunoassays, flowcytometry, cell manipulation, PCR amplification, DNA analysis, and clinical diagnosis [166]. The BV M-series 
platform (BioVeris Corp., Gaithersburg, MD) detects antigen through electrochemiluminescence and sandwich ELISA. The antibodies, tagged with BV-TAG containing ruthenium, are immobilized on paramagnetic beads, and are passed through flow cells. The bead-antigen-TAG complexes are magnetically captured, and a voltage is applied to excite the TAG to emit multiple photons. The device is capable of detecting E. coli (O157), Yersinia sp., S. Typhimurium, and toxins [167, 168].

Microfluidic chips are designed by using glass, silicon or poly dimethylsiloxan, which hold small quantities of both sample and reagent in its channels for easy separation, detection and data analysis. Due to the miniaturization of the system, it is portable, cuts down the cost, and does not require any skilled labor. Therefore, microfluidics can provide a gamut of laboratory requirements on a single chip and that can be used as POC device in clinical settings.

The microfluidics platform integrated with methods such as PCR, isothermal amplification, and microarrays rapidly detects pathogens $[117,126,137,138,161$, 169, 170]. A lab-on-centrifugal-disk has been introduced in the field of POC devices; here, isothermal amplification (reverse transcriptase-LAMP) and optical detectors are fabricated on a centrifugal microfluidic system for the detection of influenza A virus strains. This POC device has an LOD of 10 viral copies and produces results in $47 \mathrm{~min}$ [171]. These lab-on-centrifugal-disk devices are more portable and robust compared to traditional assays for viral and bacterial disease diagnosis [172]. To further move in the "sample-to-result" analysis, $3 \mathrm{M}$ and Focus diagnostics developed a direct amplification disk that can amplify and detect pathogen in $\sim 1 \mathrm{~h}$.

\subsection{Conclusion}

Molecular techniques have revolutionized the diagnosis of biothreat agents and led to the development of POC devices. A number of FDA- approved and commercialized kits and devices have been launched for the rapid and quick detection of biothreat agents to strengthen the biodefense preparedness program. Although techniques like microarrays and NGS have potential to revolutionize the detection of biothreat agents, they are time-consuming and generate huge amounts of data that require skilled personnel for interpretation. Therefore, devices or platforms should be designed that are simple and user friendly and low in cost and maintenance for use in various biothreat detection surveillance programs in the field.

\section{References}

1. Centers for Disease Control and Prevention: Emergency preparedness and response: bioterrorism agents/diseases. Centers for Disease Control and Prevention. Centers for Disease Control and Prevention. 2017. https://emergency.cdc.gov/agent/agentlist-category.asp. Accessed 20 Jun 2018.

2. Golding CG, Lamboo LL, Beniac DR, Booth TF. The scanning electron microscope in microbiology and diagnosis of infectious disease. Sci Rep. 2016;6:26516. https://doi.org/10. 1038/srep26516. 
3. Goldsmith CS, Miller SE. Modern uses of electron microscopy for detection of viruses. Clin Microbiol Rev. 2009;22:552-63. https://doi.org/10.1128/CMR.00027-09.

4. Souf S. Recent advances in diagnostic testing for viral infections. Biosci Horiz. 2016;9: hzw010. https://doi.org/10.1093/biohorizons/hzw010.

5. Bailes J, Mayoss S, Teale P, Soloviev M. Gold nanoparticle antibody conjugates for use in competitive lateral flow assays. Methods Mol Biol. 2012;906:45-55. https://doi.org/10.1007/ 978-1-61779-953-2_4.

6. Hampl J, Hall M, Mufti NA, Yao YM, MacQueen DB, Wright WH, Cooper DE. Upconverting phosphor reporters in immunochromatographic assays. Anal Biochem. 2001;288:176-87. https://doi.org/10.1006/abio.2000.4902.

7. Ortega-Vinuesa JL, Bastos-González D. A review of factors affecting the performances of latex agglutination tests. J Biomater Sci Polym Ed. 2001;12:379-408. https://doi.org/10.1163/ 156856201750195289.

8. Wang J, et al. Simultaneous detection of five biothreat agents in powder samples by a multiplexed suspension array. Immunopharmacol Immunotoxicol. 2009b;31:417-27. https:// doi.org/10.1080/08923970902740837.

9. Environics Oy. ENVI assay system; biodefence tests. Environics Oy. 2018. https://www. environics.fi/product/envi-assay-system/. Accessed 20 Jun 2018.

10. New Horizons Diagnostics Inc. SMART-II Anthrax (spore). New Horizons Diagnostics. http://www.nhdiag.com/anthrax.shtml. Accessed 20 Jun 2018.

11. Response Biomedical. Response biodefense: portable, rapid biological field detection system. Response Biomedical Inc. 2018. http://responsebio.com/biodefense. Accessed 20 June 2018.

12. GenPrime. Prime alert bio-detection system. GenPrime. 2017. http://www.genprime.com/ prime-alert. Accessed 20 Jun 2018

13. CBRNE Tech Index. Lateral flow/hand held immunoassay. MRI-Global. 2014. http://www. cbrnetechindex.com/Biological-Detection/Technology-BD/Immunological-BD-T/LateralFlow-Hand-Held-Immunoassay-BD-I. Accessed 20 Jun 2018.

14. Pal V, Sharma MK, Sharma SK, Goel AK. Biological warfare agents and their detection and monitoring techniques. Def Sci J. 2016;66:13. https://doi.org/10.14429/dsj.66.10704.

15. Gomes-Solecki MJ, Savitt AG, Rowehl R, Glass JD, Bliska JB, Dattwyler RJ. LcrV capture enzyme-linked immunosorbent assay for detection of Yersinia pestis from human samples. Clin Diagn Lab Immunol. 2005;12:339-46. https://doi.org/10.1128/CDLI.12.2.339-346.2005.

16. Jenko KL, et al. Development of an ELISA microarray assay for the sensitive and simultaneous detection of ten biodefense toxins. The Analyst. 2014;139:5093-102. https://doi.org/10. 1039/c4an01270d.

17. Saijo M, Niikura M, Morikawa S, Ksiazek TG, Meyer RF, Peters CJ, Kurane I. Enzyme-linked immunosorbent assays for detection of antibodies to Ebola and Marburg viruses using recombinant nucleoproteins. J Clin Microbiol. 2001;39:1-7. https://doi.org/10.1128/JCM.39. 1.1-7.2001.

18. Sharma N, et al. Detection of Francisella tularensis-specific antibodies in patients with tularemia by a novel competitive enzyme-linked immunosorbent assay. Clin Vaccine Immunol. 2013;20:9-16. https://doi.org/10.1128/CVI.00516-12.

19. Suttisunhakul V, et al. Development of rapid enzyme-linked immunosorbent assays for detection of antibodies to Burkholderia pseudomallei. J Clin Microbiol. 2016;54:1259-68. https://doi.org/10.1128/JCM.02856-15.

20. Tiwari AK, Kumar S, Pal V, Bhardwaj B, Rai GP. Evaluation of the recombinant 10-kilodalton immunodominant region of the BP26 protein of Brucella abortus for specific diagnosis of bovine brucellosis. Clin Vaccine Immunol. 2011;18:1760-4. https://doi.org/10. 1128/CVI.05159-11.

21. Wang DB, et al. Detection of B. anthracis spores and vegetative cells with the same monoclonal antibodies. PLoS One. 2009a;4:e7810. https://doi.org/10.1371/journal.pone.0007810.

22. McHugh S, Burnell S, Shenhav S, Svarovsky S, Manneh V. Novel time resolved fluorescence platform for near patient diagnostics. Oak Ridge Conference, Capturing Innovation: The Impact of Emerging Diagnostic Technologies; 2010 April 22-23; San Jose, CA. 
23. Peruski AH, Johnson LH III, Peruski LF Jr. Rapid and sensitive detection of biological warfare agents using time-resolved fluorescence assays. J Immunol Methods. 2002;263:35-41.

24. Tian W, Finehout E, editors. Microfluidics for biological applications. New York: Springer; 2009. https://doi.org/10.1007/978-0-387-09480-9.

25. Mohan R, Mach KE, Bercovici M, Pan Y, Dhulipala L, Wong PK, Liao JC. Clinical validation of integrated nucleic acid and protein detection on an electrochemical biosensor array for urinary tract infection diagnosis. PLoS One. 2011;6:e26846. https://doi.org/10.1371/journal. pone.0026846.

26. Sin MLY, Mach KE, Wong PK, Liao JC. Advances and challenges in biosensor-based diagnosis of infectious diseases. Expert Rev Mol Diagn. 2014;14:225-44. https://doi.org/10. 1586/14737159.2014.888313.

27. Deng S, Lei J, Cheng L, Zhang Y, Ju H. Amplified electrochemiluminescence of quantum dots by electrochemically reduced graphene oxide for nanobiosensing of acetylcholine. Biosens Bioelectron. 2011;26:4552-8. https://doi.org/10.1016/j.bios.2011.05.023.

28. Hunt HK, Armani AM. Label-free biological and chemical sensors. Nanoscale. 2010;2:1544-59. https://doi.org/10.1039/c0nr00201a.

29. Rapp BE, Gruhl FJ, Lange K. Biosensors with label-free detection designed for diagnostic applications. Anal Bioanal Chem. 2010;398:2403-12. https://doi.org/10.1007/s00216-0103906-2.

30. Wojciechowski J, Danley D, Cooper J, Yazvenko N, Taitt CR. Multiplexed electrochemical detection of Yersinia pestis and staphylococcal enterotoxin B using an antibody microarray. Sensors (Basel). 2010;10:3351-62. https://doi.org/10.3390/s100403351.

31. Pohanka M, Hubalek M, Neubauerova V, Macela A, Martin F, Bandouchova H, Pikula J. Current and tularensis detection: a review. Vet Med. 2008;53:585-94.

32. Pohanka M, Pavlis O, Skladal P. Diagnosis of tularemia using piezoelectric biosensor technology. Talanta. 2007;71:981-5. https://doi.org/10.1016/j.talanta.2006.05.074.

33. Yu JS, et al. Detection of Ebola virus envelope using monoclonal and polyclonal antibodies in ELISA, surface plasmon resonance and a quartz crystal microbalance immunosensor. J Virol Methods. 2006;137:219-28. https://doi.org/10.1016/j.jviromet.2006.06.014.

34. Pardee K, Green AA, Ferrante T, Cameron DE, DaleyKeyser A, Yin P, Collins JJ. Paper-based synthetic gene networks. Cell. 2014;159:940-54. https://doi.org/10.1016/j.cell.2014.10.004.

35. PathSensors. Introducing CANARY - cutting edge pathogen detection. PathSensors. 2018. https://pathsensors.com/technology/about-canary/. Accessed 20 Jun 2018.

36. Rider TH, et al. A B cell-based sensor for rapid identification of pathogens. Science. 2003;301:213-5. https://doi.org/10.1126/science.1084920.

37. Vidic J, Manzano M, Chang C-M, Jaffrezic-Renault N. Advanced biosensors for detection of pathogens related to livestock and poultry. Vet Res. 2018;48:11. https://doi.org/10.1186/ s13567-017-0418-5.

38. Narayanan J, Sharma MK, Ponmariappan S, Sarita SM, Upadhyay S. Electrochemical immunosensor for botulinum neurotoxin type-E using covalently ordered graphene nanosheets modified electrodes and gold nanoparticles-enzyme conjugate. Biosens Bioelectron. 2015;69:249-56. https://doi.org/10.1016/j.bios.2015.02.039.

39. Wu H, Zuo Y, Cui C, Yang W, Ma H, Wang X. Rapid quantitative detection of Brucella melitensis by a label-free impedance immunosensor based on a gold nanoparticle-modified screen-printed carbon electrode. Sensors. 2013;13:8551-63. https://doi.org/10.3390/ s130708551.

40. Sharma MK, Narayanan J, Pardasani D, Srivastava DN, Upadhyay S, Goel AK. Ultrasensitive electrochemical immunoassay for surface array protein, a Bacillus anthracis biomarker using $\mathrm{Au}-\mathrm{Pd}$ nanocrystals loaded on boron-nitride nanosheets as catalytic labels. Biosens Bioelectron. 2016;80:442-9. https://doi.org/10.1016/j.bios.2016.02.008.

41. Gupta G, Kumar A, Boopathi M, Thavaselvam D, Singh B, Vijayaraghavan R. Rapid and quantitative detection of biological warfare agent Brucella abortus CSP-31 by surface plasmon resonance. India-Japan Workshop on Biomolecular Electronics and Organic Nanotechnology for Environment Preservation; 2009; New Delhi, India. 
42. Huynh HT, Gotthard G, Terras J, Aboudharam G, Drancourt M, Chabriere E. Surface plasmon resonance imaging of pathogens: the Yersinia pestis paradigm. BMC Res Notes. 2015;8:259. https://doi.org/10.1186/s13104-015-1236-3.

43. Tomar A, Gupta G, Singh MK, Boopathi M, Singh B, Dhaked RK. Surface plasmon resonance sensing of biological warfare agent botulinum neurotoxin A. J Bioterror Biodef. 2016;7:142. https://doi.org/10.4172/2157-2526.1000142.

44. Pohanka M, Skladal P. Piezoelectric immunosensor for Francisella tularensis detection using immunoglobulin M in a limiting dilution. Anal Lett. 2005;38:411-22. https://doi.org/10.1081/ Al-200047764.

45. Salmain M, Ghasemi M, Boujday S, Pradier CM. Elaboration of a reusable immunosensor for the detection of staphylococcal enterotoxin A (SEA) in milk with a quartz crystal microbalance. Sens Actuators B Chem. 2012;173:148-56. https://doi.org/10.1016/j.snb.2012.06.052.

46. Vunsh R, Rosner A, Stein A. The use of the polymerase chain-reaction (PCR) for the detection of bean yellow mosaic-virus in gladiolus. Ann Appl Biol. 1990;117:561-9. https://doi.org/10. 1111/j.1744-7348.1990.tb04822.x.

47. Cheng VC, Lau SK, Woo PC, Yuen KY. Severe acute respiratory syndrome coronavirus as an agent of emerging and reemerging infection. Clin Microbiol Rev. 2007;20:660-94. https://doi. org/10.1128/CMR.00023-07.

48. Mahony JB. Nucleic acid amplification-based diagnosis of respiratory virus infections. Expert Rev Anti-Infect Ther. 2010;8:1273-92. https://doi.org/10.1586/eri.10.121.

49. Ntziora F, et al. Ultrasensitive amplification refractory mutation system real-time PCR (ARMS RT-PCR) assay for detection of minority hepatitis B virus-resistant strains in the era of personalized medicine. J Clin Microbiol. 2013;51:2893-900. https://doi.org/10.1128/JCM. 00936-13.

50. Valle L, et al. Performance testing of two new one-step real time PCR assays for detection of human influenza and avian influenza viruses isolated in humans and respiratory syncytial virus. J Prev Med Hyg. 2006;47:127-33.

51. Zhang WD, Evans DH. Detection and identification of human influenza viruses by the polymerase chain reaction. J Virol Methods. 1991;33:165-89.

52. Boonham N, Kreuze J, Winter S, van der Vlugt R, Bergervoet J, Tomlinson J, Mumford R. Methods in virus diagnostics: from ELISA to next generation sequencing. Virus Res. 2014;186:20-31. https://doi.org/10.1016/j.virusres.2013.12.007.

53. Huang Y, Wei H, Wang Y, Shi Z, Raoul H, Yuan Z. Rapid detection of filoviruses by real-time TaqMan polymerase chain reaction assays. Virol Sin. 2012;27:273-7. https://doi.org/10.1007/ s12250-012-3252-y.

54. Trombley AR, et al. Comprehensive panel of real-time TaqMan polymerase chain reaction assays for detection and absolute quantification of filoviruses, arenaviruses, and New World hantaviruses. Am J Trop Med Hyg. 2010;82:954-60. https://doi.org/10.4269/ajtmh.2010.090636.

55. Kurth A, et al. Novel paramyxoviruses in free-ranging European bats. PLoS One. 2012;7: e38688. https://doi.org/10.1371/journal.pone.0038688.

56. Wilkinson DA, et al. Identification of novel paramyxoviruses in insectivorous bats of the Southwest Indian Ocean. Virus Res. 2012;170:159-63. https://doi.org/10.1016/j.virusres. 2012.08.022.

57. Lipkin WI, Anthony SJ. Virus hunting. Virology. 2015;479-480:194-9. https://doi.org/10. 1016/j.virol.2015.02.006.

58. Zambon M, Hays J, Webster A, Newman R, Keene O. Diagnosis of influenza in the community: relationship of clinical diagnosis to confirmed virological, serologic, or molecular detection of influenza. Arch Intern Med. 2001;161:2116-22.

59. Mahony JB. Detection of respiratory viruses by molecular methods. Clin Microbiol Rev. 2008;21:716-47. https://doi.org/10.1128/CMR.00037-07.

60. Ellis JS, Fleming DM, Zambon MC. Multiplex reverse transcription-PCR for surveillance of influenza A and B viruses in England and Wales in 1995 and 1996. J Clin Microbiol. 1997;35:2076-82. 
61. Thornton SA, Sherman SS, Farkas T, Zhong W, Torres P, Jiang X. Gastroenteritis in US Marines during Operation Iraqi Freedom. Clin Infect Dis. 2005;40:519-25. https://doi.org/10. $1086 / 427501$.

62. Drosten C, Gottig S, Schilling S, Asper M, Panning M, Schmitz H, Gunther S. Rapid detection and quantification of RNA of Ebola and Marburg viruses, Lassa virus, Crimean-Congo hemorrhagic fever virus, Rift Valley fever virus, dengue virus, and yellow fever virus by real-time reverse transcription-PCR. J Clin Microbiol. 2002;40:2323-30.

63. Yang Y, Bai L, Hu KX, Yang ZH, Hu JP, Wang J. Multiplex real-time PCR method for rapid detection of Marburg virus and Ebola virus. Chin J Exp Clin Virol. 2012;26:313-5.

64. Abd El Wahed A, Patel P, Heidenreich D, Hufert FT, Weidmann M. Reverse transcription recombinase polymerase amplification assay for the detection of middle East respiratory syndrome coronavirus. PLoS Curr. 2013:5. https://doi.org/10.1371/currents.outbreaks. 62df1c7c75ffc96cd59034531e2e8364.

65. Nguyen TT, Van Giau V, Vo TK. Multiplex PCR for simultaneous identification of E. coli O157:H7, Salmonella spp. and L. monocytogenes in food. 3 Biotech. 2016;6:205. https://doi. org/10.1007/s13205-016-0523-6.

66. Metzgar D, et al. The IRIDICA BAC BSI assay: rapid, sensitive and culture-independent identification of bacteria and Candida in blood. PLoS One. 2016;11:e0158186. https://doi.org/ 10.1371/journal.pone.0158186.

67. Pillet S, et al. Comparative evaluation of six commercialized multiplex PCR kits for the diagnosis of respiratory infections. PLoS One. 2013;8:e72174. https://doi.org/10.1371/jour nal.pone.0072174.

68. Legoff J, Kara R, Moulin F, Si-Mohamed A, Krivine A, Belec L, Lebon P. Evaluation of the one-step multiplex real-time reverse transcription-PCR ProFlu-1 assay for detection of influenza A and influenza B viruses and respiratory syncytial viruses in children. J Clin Microbiol. 2008;46:789-91. https://doi.org/10.1128/jcm.00959-07.

69. Banada PP, et al. Rapid detection of Bacillus anthracis bloodstream infections by use of a novel assay in the GeneXpert system. J Clin Microbiol. 2017;55:2964-71. https://doi.org/10. 1128/jcm.00466-17.

70. Boehme CC, et al. Rapid molecular detection of tuberculosis and rifampin resistance. N Engl J Med. 2010;363:1005-15. https://doi.org/10.1056/NEJMoa0907847.

71. Boehme CC, et al. Feasibility, diagnostic accuracy, and effectiveness of decentralised use of the Xpert MTB/RIF test for diagnosis of tuberculosis and multidrug resistance: a multicentre implementation study. Lancet (London, England). 2011;377:1495-505. https://doi.org/10. 1016/s0140-6736(11)60438-8.

72. Lawn SD, et al. Advances in tuberculosis diagnostics: the Xpert MTB/RIF assay and future prospects for a point-of-care test. Lancet Infect Dis. 2013;13:349-61. https://doi.org/10.1016/ S1473-3099(13)70008-2.

73. Lawn SD, Nicol MP. Xpert(R) MTB/RIF assay: development, evaluation and implementation of a new rapid molecular diagnostic for tuberculosis and rifampicin resistance. Future Microbiol. 2011;6:1067-82. https://doi.org/10.2217/fmb.11.84.

74. Rossney AS, Herra CM, Brennan GI, Morgan PM, O'Connell B. Evaluation of the Xpert methicillin-resistant Staphylococcus aureus (MRSA) assay using the GeneXpert real-time PCR platform for rapid detection of MRSA from screening specimens. J Clin Microbiol. 2008;46:3285-90. https://doi.org/10.1128/JCM.02487-07.

75. Jansen van Vuren $P$, et al. Comparative evaluation of the diagnostic performance of the prototype cepheid GeneXpert Ebola Assay. J Clin Microbiol. 2016;54:359-67. https://doi. org/10.1128/jcm.02724-15.

76. Semper AE, et al. Performance of the GeneXpert Ebola assay for diagnosis of ebola virus disease in sierra leone: a field evaluation study. PLoS Med. 2016;13:e1001980. https://doi.org/ 10.1371/journal.pmed.1001980.

77. Van den Bergh R, et al. Feasibility of Xpert Ebola assay in Medecins Sans Frontieres Ebola program, Guinea. Emerg Infect Dis. 2016;22:210-6. https://doi.org/10.3201/eid2202.151238. 
78. Jang YR, et al. Molecular detection of Coxiella burnetii from the formalin-fixed tissues of Q fever patients with acute hepatitis. PLoS One. 2017;12:e0180237. https://doi.org/10.1371/ journal.pone.0180237.

79. Rolain JM, Raoult D. Molecular detection of Coxiella burnetii in blood and sera during Q fever. QJM. 2005;98:615-7.; author reply 617-620. https://doi.org/10.1093/qjmed/hci099.

80. Pradeep J, Stephen S, Ambroise S, Gunasekaran D. Diagnosis of acute Q fever by detection of Coxiella burnetii DNA using real-time PCR, employing a commercial genesig easy kit. J Clin Diagn Res. 2017;11:Dc10-dc13. https://doi.org/10.7860/jcdr/2017/31005.10606.

81. Espy MJ, Cockerill IF, Meyer RF, Bowen MD, Poland GA, Hadfield TL, Smith TF. Detection of smallpox virus DNA by LightCycler PCR. J Clin Microbiol. 2002;40:1985-8.

82. Ecker DJ, et al. New technology for rapid molecular diagnosis of bloodstream infections. Expert Rev Mol Diagn. 2010;10:399-415. https://doi.org/10.1586/erm.10.24.

83. Sampath R, et al. Comprehensive biothreat cluster identification by PCR/electrosprayionization mass spectrometry. PLoS One. 2012;7:e36528. https://doi.org/10.1371/journal. pone.0036528.

84. Barzon L, Lavezzo E, Militello V, Toppo S, Palu G. Applications of next-generation sequencing technologies to diagnostic virology. Int J Mol Sci. 2011;12:7861-84. https://doi.org/10. 3390/ijms12117861.

85. Beggs ML, Stevanova R, Eisenach KD. Species identification of Mycobacterium avium complex isolates by a variety of molecular techniques. J Clin Microbiol. 2000;38:508-12.

86. Briese T, et al. Genetic detection and characterization of Lujo virus, a new hemorrhagic feverassociated arenavirus from southern Africa. PLoS Pathog. 2009;5:e1000455. https://doi.org/ 10.1371/journal.ppat.1000455.

87. Highlander SK, et al. Subtle genetic changes enhance virulence of methicillin resistant and sensitive Staphylococcus aureus. BMC Microbiol. 2007;7:99. https://doi.org/10.1186/14712180-7-99.

88. Hoffmann C, Minkah N, Leipzig J, Wang G, Arens MQ, Tebas P, Bushman FD. DNA bar coding and pyrosequencing to identify rare HIV drug resistance mutations. Nucleic Acids Res. 2007;35:e91. https://doi.org/10.1093/nar/gkm435.

89. Menegazzi P, Reho E, Ulivi M, Varnier OE, Lillo FB, Tagliaferro L. Rapid and accurate quantification of different HCV genotypes by LightCycler Real Time PCR and direct sequencing of HCV amplicons. New Microbiol. 2008;31:181-7.

90. Wang C, Mitsuya Y, Gharizadeh B, Ronaghi M, Shafer RW. Characterization of mutation spectra with ultra-deep pyrosequencing: application to HIV-1 drug resistance. Genome Res. 2007;17:1195-201. https://doi.org/10.1101/gr.6468307.

91. Lam HY, et al. Performance comparison of whole-genome sequencing platforms. Nat Biotechnol. 2011;30:78-82. https://doi.org/10.1038/nbt.2065.

92. Wang Z, Gerstein M, Snyder M. RNA-Seq: a revolutionary tool for transcriptomics. Nat Rev Genet. 2009c;10:57-63. https://doi.org/10.1038/nrg2484.

93. Kuroda M, Sekizuka T, Shinya F, Takeuchi F, Kanno T, Sata T, Asano S. Detection of a possible bioterrorism agent, Francisella sp., in a clinical specimen by use of next-generation direct DNA sequencing. J Clin Microbiol. 2012;50:1810-2. https://doi.org/10.1128/JCM. 06715-11.

94. Margulies M, et al. Genome sequencing in microfabricated high-density picolitre reactors. Nature. 2005;437:376. https://doi.org/10.1038/nature03959.. https://www.nature.com/articles/ nature03959\#supplementary-information

95. Pearson BM, Gaskin DJ, Segers RP, Wells JM, Nuijten PJ, van Vliet AH. The complete genome sequence of Campylobacter jejuni strain 81116 (NCTC11828). J Bacteriol. 2007;189:8402-3. https://doi.org/10.1128/JB.01404-07.

96. Illumina. Sequencing platform comparison tool. Illumina. 2018. www.illumina.com/systems/ sequencing-platforms/comparison-tool.html. Accessed 20 Jun 2018. 
97. Be NA, et al. Detection of Bacillus anthracis DNA in complex soil and air samples using nextgeneration sequencing. PLoS One. 2013;8:e73455. https://doi.org/10.1371/journal.pone. 0073455 .

98. Ramalingam NSP. Concepts and techniques in genomics and proteomics. Woodhead Publishing Series in Biomedicine. 2011.

99. Shendure J, Ji H. Next-generation DNA sequencing. Nat Biotechnol. 2008;26:1135-45. https://doi.org/10.1038/nbt1486.

100. Voelkerding KV, Dames SA, Durtschi JD. Next-generation sequencing: from basic research to diagnostics. Clin Chem. 2009;55:641-58. https://doi.org/10.1373/clinchem.2008.112789.

101. Cummings CA, et al. Accurate, rapid and high-throughput detection of strain-specific polymorphisms in Bacillus anthracis and Yersinia pestis by next-generation sequencing. Investig Genet. 2010;1:5. https://doi.org/10.1186/2041-2223-1-5.

102. Loman NJ, Misra RV, Dallman TJ, Constantinidou C, Gharbia SE, Wain J, Pallen MJ. Performance comparison of benchtop high-throughput sequencing platforms. Nat Biotechnol. 2012;30:434-9. https://doi.org/10.1038/nbt.2198.

103. Feng H, Shuda M, Chang Y, Moore PS. Clonal integration of a polyomavirus in human Merkel cell carcinoma. Science. 2008;319:1096-100. https://doi.org/10.1126/science. 1152586.

104. Feng $\mathrm{H}$, et al. Human transcriptome subtraction by using short sequence tags to search for tumor viruses in conjunctival carcinoma. J Virol. 2007;81:11332-40. https://doi.org/10.1128/ JVI.00875-07.

105. Grard G, et al. A novel rhabdovirus associated with acute hemorrhagic fever in central Africa. PLoS Pathog. 2012;8:e1002924. https://doi.org/10.1371/journal.ppat.1002924.

106. Tong YG, et al. Genetic diversity and evolutionary dynamics of Ebola virus in Sierra Leone. Nature. 2015;524:93-6. https://doi.org/10.1038/nature14490.

107. Schena M, Shalon D, Davis RW, Brown PO. Quantitative monitoring of gene expression patterns with a complementary DNA Microarray. Science. 1995;270:467-70.

108. Hughes TR, et al. Expression profiling using microarrays fabricated by an ink-jet oligonucleotide synthesizer. Nat Biotechnol. 2001;19:342-7. https://doi.org/10.1038/86730.

109. Pease AC, Solas D, Sullivan EJ, Cronin MT, Holmes CP, Fodor SP. Light-generated oligonucleotide arrays for rapid DNA sequence analysis. Proc Natl Acad Sci U S A. 1994;91:5022-6.

110. Leski TA, et al. Testing and validation of high density resequencing microarray for broad range biothreat agents detection. PLoS One. 2009;4:e6569. https://doi.org/10.1371/journal. pone.0006569.

111. Wang D, Coscoy L, Zylberberg M, Avila PC, Boushey HA, Ganem D, DeRisi JL. Microarraybased detection and genotyping of viral pathogens. Proc Natl Acad Sci U S A. 2002;99:15687-92. https://doi.org/10.1073/pnas.242579699.

112. Wang D, et al. Viral discovery and sequence recovery using DNA microarrays. PLoS Biol. 2003;1:E2. https://doi.org/10.1371/journal.pbio.0000002.

113. Chou C-C, et al. Design of microarray probes for virus identification and detection of emerging viruses at the genus level. BMC Bioinf. 2006;7:232. https://doi.org/10.1186/1471-2105-7232.

114. Chiu CY, et al. Utility of DNA microarrays for detection of viruses in acute respiratory tract infections in children. J Pediatr. 2008;153:76-83. https://doi.org/10.1016/j.jpeds.2007.12.035.

115. Palacios G, et al. Panmicrobial oligonucleotide array for diagnosis of infectious diseases. Emerg Infect Dis. 2007;13:73-81. https://doi.org/10.3201/eid1301.060837.

116. Boriskin YS, Rice PS, Stabler RA, Hinds J, Al-Ghusein H, Vass K, Butcher PD. DNA microarrays for virus detection in cases of central nervous system infection. J Clin Microbiol. 2004;42:5811-8. https://doi.org/10.1128/jcm.42.12.5811-5818.2004.

117. Liu RH, Lodes MJ, Nguyen T, Siuda T, Slota M, Fuji HS, McShea A. Validation of a fully integrated microfluidic array device for influenza A subtype identification and sequencing. Anal Chem. 2006;78:4184-93. https://doi.org/10.1021/ac060450v. 
118. Myers KM, Gaba J, Al-Khaldi SF. Molecular identification of Yersinia enterocolitica isolated from pasteurized whole milk using DNA microarray chip hybridization. Mol Cell Probes. 2006;20:71-80. https://doi.org/10.1016/j.mcp.2005.09.006.

119. Bennett BD. Blood glucose determination: point of care testing. South Med J. 1997;90:678-80.

120. Compton J. Nucleic acid sequence-based amplification. Nature. 1991;350:91-2. https://doi. org/10.1038/350091a0.

121. Guatelli JC, Whitfield KM, Kwoh DY, Barringer KJ, Richman DD, Gingeras TR. Isothermal, in vitro amplification of nucleic acids by a multienzyme reaction modeled after retroviral replication. Proc Natl Acad Sci U S A. 1990;87:7797.

122. Greer S, Alexander GJ. Viral Serology and Detection. Baillieres Clin Gastroenterol. 1995;9:689-721.

123. Niemz A, Ferguson TM, Boyle DS. Point-of-care nucleic acid testing for infectious diseases. Trends Biotechnol. 2011;29:240-50. https://doi.org/10.1016/j.tibtech.2011.01.007.

124. Troger V, Niemann K. Isothermal amplification and quantification of nucleic acids and its use in microsystems. J Nanomed Nanotechnol. 2015;6:1-19. https://doi.org/10.4172/2157-7439.

125. Hall MJ, Wharam SD, Weston A, Cardy DL, Wilson WH. Use of signal-mediated amplification of RNA technology (SMART) to detect marine cyanophage DNA BioTechniques. 2002;32:604-606, 608-611.

126. McCalla SE, Ong C, Sarma A, Opal SM, Artenstein AW, Tripathi A. A simple method for amplifying RNA targets (SMART). J Mol Diagn. 2012;14:328-35. https://doi.org/10.1016/j. jmoldx.2012.02.001.

127. Wharam SD, et al. Specific detection of DNA and RNA targets using a novel isothermal nucleic acid amplification assay based on the formation of a three-way junction structure. Nucleic Acids Res. 2001;29:e54.

128. Bonney LC, Watson RJ, Afrough B, Mullojonova M, Dzhuraeva V, Tishkova F, Hewson R. A recombinase polymerase amplification assay for rapid detection of Crimean-Congo Haemorrhagic fever Virus infection. PLoS Negl Trop Dis. 2017;11:e0006013. https://doi. org/10.1371/journal.pntd.0006013.

129. Mayboroda O, et al. Isothermal solid-phase amplification system for detection of Yersinia pestis. Anal Bioanal Chem. 2016;408:671-6. https://doi.org/10.1007/s00216-015-9177-1.

130. Koo B, et al. A rapid bio-optical sensor for diagnosing Q fever in clinical specimens. J Biophotonics. 2018;11:e201700167. https://doi.org/10.1002/jbio.201700167.

131. Euler M, et al. Development of a panel of recombinase polymerase amplification assays for detection of biothreat agents. J Clin Microbiol. 2013;51:1110-7. https://doi.org/10.1128/jcm. 02704-12.

132. Vincent M, Xu Y, Kong H. Helicase-dependent isothermal DNA amplification. EMBO Rep. 2004;5:795-800. https://doi.org/10.1038/sj.embor.7400200.

133. An L, Tang W, Ranalli TA, Kim HJ, Wytiaz J, Kong H. Characterization of a thermostable UvrD helicase and its participation in helicase-dependent amplification. J Biol Chem. 2005;280:28952-8. https://doi.org/10.1074/jbc.M503096200.

134. Goldmeyer J, Kong H, Tang W. Development of a novel one-tube isothermal reverse transcription thermophilic helicase-dependent amplification platform for rapid RNA detection. J Mol Diagn. 2007;9:639-44. https://doi.org/10.2353/jmoldx.2007.070012.

135. Kivlehan F, Mavre F, Talini L, Limoges B, Marchal D. Real-time electrochemical monitoring of isothermal helicase-dependent amplification of nucleic acids. Analyst. 2011;136:3635-42. https://doi.org/10.1039/c1an15289k.

136. Torres-Chavolla E, Alocilja EC. Nanoparticle based DNA biosensor for tuberculosis detection using thermophilic helicase-dependent isothermal amplification. Biosens Bioelectron. 2011;26:4614-8. https://doi.org/10.1016/j.bios.2011.04.055.

137. Zhang Y, Park S, Liu K, Tsuan J, Yang S, Wang TH. A surface topography assisted droplet manipulation platform for biomarker detection and pathogen identification. Lab Chip. 2011;11:398-406. https://doi.org/10.1039/c0lc00296h. 
138. Andresen D, von Nickisch-Rosenegk M, Bier FF. Helicase dependent OnChip-amplification and its use in multiplex pathogen detection Clinica chimica acta. Int $\mathrm{J}$ Clin Chem. 2009;403:244-8. https://doi.org/10.1016/j.cca.2009.03.021.

139. Tong Y, Tang W, Kim HJ, Pan X, Ranalli T, Kong H. Development of isothermal TaqMan assays for detection of biothreat organisms. BioTechniques. 2008;45:543-57. https://doi.org/ $10.2144 / 000112959$.

140. Motre A, Kong R, Li Y. Improving isothermal DNA amplification speed for the rapid detection of Mycobacterium tuberculosis. J Microbiol Methods. 2011;84:343-5. https://doi. org/10.1016/j.mimet.2010.12.002.

141. Blanco L, Bernad A, Lazaro JM, Martin G, Garmendia C, Salas M. Highly efficient DNA synthesis by the phage phi 29 DNA polymerase. Symmetrical mode of DNA replication. J Biol Chem. 1989;264:8935-40.

142. Beyer S, Nickels P, Simmel FC. Periodic DNA nanotemplates synthesized by rolling circle amplification. Nano Lett. 2005;5:719-22. https://doi.org/10.1021/n1050155a.

143. Schweitzer B, Kingsmore S. Combining nucleic acid amplification and detection. Curr Opin Biotechnol. 2001;12:21-7.

144. Murakami T, Sumaoka J, Komiyama M. Sensitive isothermal detection of nucleic-acid sequence by primer generation-rolling circle amplification. Nucleic Acids Res. 2009;37:e19. https://doi.org/10.1093/nar/gkn1014.

145. Sato K, et al. Microbead-based rolling circle amplification in a microchip for sensitive DNA detection. Lab Chip. 2010;10:1262-6. https://doi.org/10.1039/b927460j.

146. Xiang Y, Zhu X, Huang Q, Zheng J, Fu W. Real-time monitoring of mycobacterium genomic DNA with target-primed rolling circle amplification by a Au nanoparticle-embedded SPR biosensor. Biosens Bioelectron. 2015;66:512-9. https://doi.org/10.1016/j.bios.2014.11.021.

147. Wang B, et al. Rapid and sensitive detection of severe acute respiratory syndrome coronavirus by rolling circle amplification. J Clin Microbiol. 2005;43:2339-44. https://doi.org/10.1128/ jcm.43.5.2339-2344.2005.

148. Hamidi SV, Ghourchian H. Colorimetric monitoring of rolling circle amplification for detection of H5N1 influenza virus using metal indicator. Biosens Bioelectron. 2015;72:121-6. https://doi.org/10.1016/j.bios.2015.04.078.

149. Hamidi SV, Ghourchian H, Tavoosidana G. Real-time detection of H5N1 influenza virus through hyperbranched rolling circle amplification. The Analyst. 2015;140:1502-9. https:// doi.org/10.1039/c4an01954g.

150. Mahmoudian L, Kaji N, Tokeshi M, Nilsson M, Baba Y. Rolling circle amplification and circle-to-circle amplification of a specific gene integrated with electrophoretic analysis on a single chip. Anal Chem. 2008a;80:2483-90. https://doi.org/10.1021/ac702289j.

151. Mahmoudian L, et al. Microchip electrophoresis for specific gene detection of the pathogenic bacteria V. cholerae by circle-to-circle amplification. Anal Sci. 2008b;24:327-32.

152. Gomez A, Miller NS, Smolina I. Visual detection of bacterial pathogens via PNA-based padlock probe assembly and isothermal amplification of DNAzymes. Anal Chem. 2014;86:11992-8. https://doi.org/10.1021/ac5018748.

153. Notomi T, Okayama H, Masubuchi H, Yonekawa T, Watanabe K, Amino N, Hase T. Loopmediated isothermal amplification of DNA. Nucleic Acids Res. 2000;28:E63.

154. Hong TC, et al. Development and evaluation of a novel loop-mediated isothermal amplification method for rapid detection of severe acute respiratory syndrome coronavirus. J Clin Microbiol. 2004;42:1956-61.

155. Parida M, Posadas G, Inoue S, Hasebe F, Morita K. Real-time reverse transcription loopmediated isothermal amplification for rapid detection of West Nile virus. J Clin Microbiol. 2004;42:257-63.

156. Mori Y, Nagamine K, Tomita N, Notomi T. Detection of loop-mediated isothermal amplification reaction by turbidity derived from magnesium pyrophosphate formation. Biochem Biophys Res Commun. 2001;289:150-4. https://doi.org/10.1006/bbrc.2001.5921. 
157. Mori Y, Kitao M, Tomita N, Notomi T. Real-time turbidimetry of LAMP reaction for quantifying template DNA. J Biochem Biophys Methods. 2004;59:145-57. https://doi.org/ 10.1016/j.jbbm.2003.12.005.

158. Soliman H, El-Matbouli M. An inexpensive and rapid diagnostic method of Koi Herpesvirus (KHV) infection by loop-mediated isothermal amplification. Virol J. 2005;2:83. https://doi. org/10.1186/1743-422X-2-83.

159. Yoda T, Suzuki Y, Yamazaki K, Sakon N, Kanki M, Aoyama I, Tsukamoto T. Evaluation and application of reverse transcription loop-mediated isothermal amplification for detection of noroviruses. J Med Virol. 2007;79:326-34. https://doi.org/10.1002/jmv.20802.

160. Fang X, Liu Y, Kong J, Jiang X. Loop-mediated isothermal amplification integrated on microfluidic chips for point-of-care quantitative detection of pathogens. Anal Chem. 2010;82:3002-6. https://doi.org/10.1021/ac1000652.

161. Wang CH, Lien KY, Wu JJ, Lee GB. A magnetic bead-based assay for the rapid detection of methicillin-resistant Staphylococcus aureus by using a microfluidic system with integrated loop-mediated isothermal amplification. Lab Chip. 2011;11:1521-31. https://doi.org/10.1039/ c0lc00430h.

162. Ahmed MU, Nahar S, Safavieh M, Zourob M. Real-time electrochemical detection of pathogen DNA using electrostatic interaction of a redox probe. Analyst. 2013;138:907-15. https:// doi.org/10.1039/c2an36153a.

163. He Y, Zeng K, Zhang S, Gurung AS, Baloda M, Zhang X, Liu G. Visual detection of gene mutations based on isothermal strand-displacement polymerase reaction and lateral flow strip. Biosens Bioelectron. 2012;31:310-5. https://doi.org/10.1016/j.bios.2011.10.037.

164. Yang JM, et al. An integrated, stacked microlaboratory for biological agent detection with DNA and immunoassays. Biosens Bioelectron. 2002;17:605-18.

165. Westin L, Xu X, Miller C, Wang L, Edman CF, Nerenberg M. Anchored multiplex amplification on a microelectronic chip array. Nat Biotechnol. 2000;18:199-204. https://doi.org/10. $1038 / 72658$.

166. Ong SE, Zhang S, Du H, Fu Y. Fundamental principles and applications of microfluidic systems. Front Biosci. 2008;13:2757-73.

167. Shelton DR, Karns JS. Quantitative detection of Escherichia coli O157 in surface waters by using immunomagnetic electrochemiluminescence. Appl Environ Microbiol. 2001;67:2908-15. https://doi.org/10.1128/AEM.67.7.2908-2915.2001.

168. Yu H, Bruno JG. Immunomagnetic-electrochemiluminescent detection of Escherichia coli O157 and Salmonella typhimurium in foods and environmental water samples. Appl Environ Microbiol. 1996;62:587-92.

169. Gulliksen A, Solli L, Karlsen F, Rogne H, Hovig E, Nordstrom T, Sirevag R. Real-time nucleic acid sequence-based amplification in nanoliter volumes. Anal Chem. 2004;76:9-14. https://doi.org/10.1021/ac034779h.

170. Gulliksen A, et al. Parallel nanoliter detection of cancer markers using polymer microchips. Lab Chip. 2005;5:416-20. https://doi.org/10.1039/b415525d.

171. Jung JH, Park BH, Oh SJ, Choi G, Seo TS. Integration of reverse transcriptase loop-mediated isothermal amplification with an immunochromatographic strip on a centrifugal microdevice for influenza A virus identification. Lab Chip. 2015;15:718-25. https://doi.org/10.1039/ c4lc01033g.

172. Gorkin R, et al. Centrifugal microfluidics for biomedical applications. Lab Chip. 2010;10:1758-73. https://doi.org/10.1039/B924109D. 